\title{
Early Carboniferous (Late Tournaisian-Early Viséan) ostracods from the Ballagan Formation, central Scotland, UK
}

\author{
MARK WILLIAMS ${ }^{1,2}$, MICHAEL STEPHENSON ${ }^{1}$, IAN P. WILKINSON ${ }^{1}$, MELANIE J. LENG ${ }^{3}$ \& C. GILES MILLER ${ }^{4}$ \\ ${ }^{1}$ British Geological Survey, Keyworth, Nottingham NG12 5GG, UK. \\ ${ }^{2}$ Current address: British Antarctic Survey, Geological Sciences Division, High Cross, Madingley Road, Cambridge CB3 0ET, UK \\ (e-mail: mwilli@bas.ac. uk). \\ ${ }^{3}$ NERC Isotope Geosciences Laboratory, British Geological Survey, Keyworth, Nottingham NG12 5GG, UK. \\ ${ }^{4}$ Natural History Museum, Cromwell Road, South Kensington, London SW7 5BD, UK.
}

\begin{abstract}
The Ballagan Formation (Late Tournaisian-Early Viséan) of central Scotland yields an ostracod fauna of 14 species in ten genera, namely Beyrichiopsis, Cavellina, Glyptolichvinella, Glyptopleura, Knoxiella, Paraparchites, Sansabella, Shemonaella, Silenites and Sulcella. The ostracods, in combination with palynomorphs, are important biostratigraphical indices for correlating the rock sequences, where other means of correlation, especially goniatites, conodonts, foraminifera, brachiopods or corals are absent. Stratigraphical distribution of the ostracods, calibrated with well-established palynomorph biozones, identifies three informally defined intervals: a sub-CM palynomorph Biozone interval with poor ostracod assemblages including Shemonaella scotoburdigalensis; a succeeding interval within the CM palynomorph Biozone where Cavellina coela, Cavellina incurvescens, Sansabella amplectans and the new species Knoxiella monarchella and Paraparchites discus first appear; and, an upper interval, in the upper CM Biozone, marked by the appearance of Sulcella affiliata. At least locally in central Scotland, S. affiliata permits a level of resolution equivalent to a sub-zonal upper division of the CM Biozone. The fauna, flora, sedimentology and stable isotope composition $\left(\delta^{13} \mathrm{C}\right.$ and $\left.\delta^{18} \mathrm{O}\right)$ of carbonate minerals in the Ballagan Formation suggest the ostracods inhabited brackish, hypersaline and ephemeral aquatic ecologies in a coastal floodplain setting. J. Micropalaeontol. 24(1): 77-94, May 2005.
\end{abstract}

KEYWORDS: Carboniferous, Tournaisian, ostracods, biostratigraphy, palaeoenvironments

\section{INTRODUCTION}

During Dinantian times, central Scotland underwent a change from terrestrial semi-arid conditions that prevailed during the Devonian and earliest Carboniferous, and gradually became affected by widespread marine transgressions (Wilson, 1989), which reached their maximum effect during deposition of the Lower Limestone Formation (Fig. 1). This history is reflected in the palaeontology of the Inverclyde Group, which is largely barren of biostratigraphically useful marine macrofossils. Even the upper, more marine parts of the Strathclyde Group contain few biostratigraphically useful marine macrofossils (Wilson, 1989). However, spores of land plants and crustacean ostracods are abundant in the Dinantian succession and a scheme of Carboniferous palynomorph biozones, in ascending order the $\mathrm{CM}, \mathrm{Pu}, \mathrm{TS}, \mathrm{TC}, \mathrm{NM}$ and VF biozones, was proposed by Neves et al. (1972, 1973), to deal with successions mainly from eastern Scotland and northern England (Fig. 1).

The Ballagan Formation is the second unit of the Dinantian sequence in Scotland (Fig. 1) and was established by Young $(1867 \mathrm{a}, \mathrm{b})$ for the mudstone and 'cementstone' sequence at Ballagan Glen, north of Glasgow [National Grid Reference NS 572 800]. The base of the formation is positioned at the boundary with the underlying, mainly Old Red Sandstone facies, Kinnesswood Formation (Fig. 1). The upper boundary is placed at the change from mudstone and 'cementstone' of the Ballagan Formation to the arenaceous Clyde Sandstone Formation (Browne et al., 1999). Its maximum thickness is $900 \mathrm{~m}$ (Mitchell \& Mykura, 1962, p. 38).

The Ballagan Formation is exposed in coastal outcrops of Ayrshire, East Lothian and Fife and is known also from numerous inland localities and several boreholes extending across central Scotland (Stephenson et al., 2003, 2004a, b; Fig. 2). It contains an ostracod fauna of 14 species, including those described in open nomenclature. As part of an ongoing British Geological Survey Mapping Project in the Midland Valley of Scotland, the ostracods have been used as a tool for correlating Tournaisian-Early Viséan rock sequences. The focus of this paper is threefold: to record the biostratigraphical distribution of these ostracods in five key sections through the Ballagan Formation, where other means of biostratigraphical correlation - except palynomorphs, are rare; to make a provisional assessment of their ecological setting; and to provide modern illustrations of the Scottish material, much of which has not been illustrated since the 1890s. The ostracod fauna comprises species of Beyrichiopsis, Cavellina, Glyptolichvinella, Glyptopleura, Knoxiella (K. monarchella sp. nov.), Paraparchites ( $P$. discus sp. nov.), Sansabella, Shemonaella, Silenites and Sulcella. New records from Scotland extend the biostratigraphical ranges of several species, enabling a revision of the stratigraphy of British Carboniferous ostracods presented by Robinson (1978).

\section{KEY SECTIONS AND MATERIAL}

Ballagan Formation ostracods from coastal and inland sections in Ayrshire and from several boreholes were assessed (Fig. 2). These provide coverage of the Ballagan Formation across the Midland Valley of Scotland. Over 350 ostracodbearing horizons were examined, yielding several thousand specimens. Micropalaeontology residues and picked material from these samples are housed at the British Geological Survey, 
M. Williams et al.

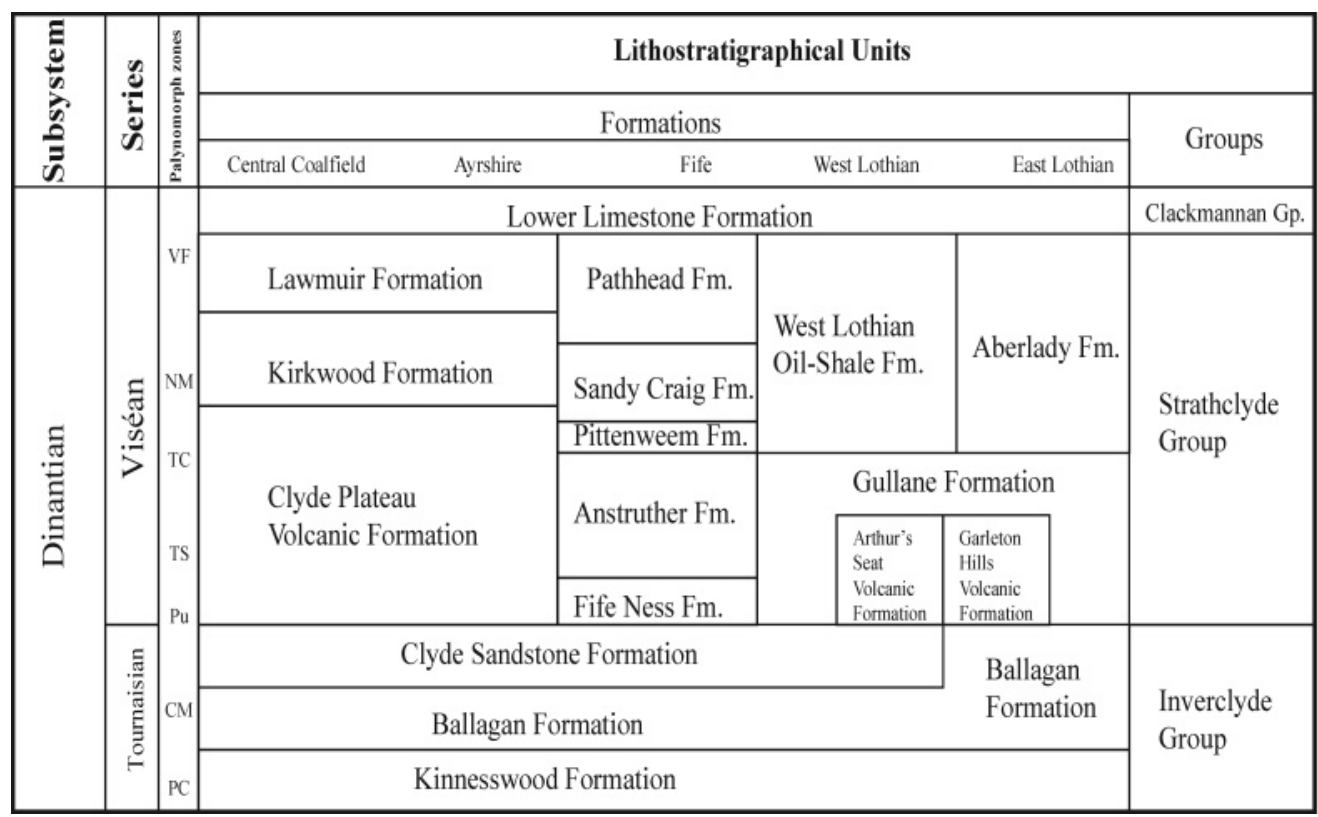

Fig. 1. Stratigraphical setting of the Ballagan Formation within the Early Carboniferous rock succession of central Scotland. Also shown is the palynomorph biozonation of Neves et al. $(1972,1973)$.
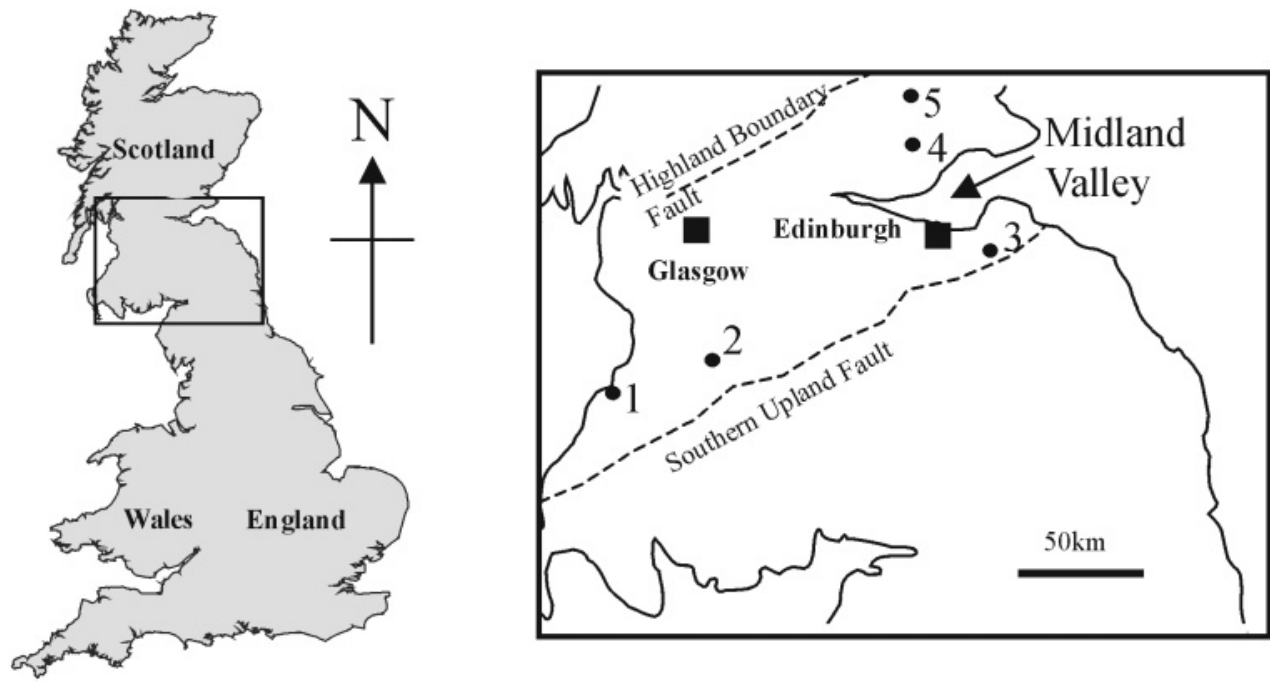

Fig. 2. Key ostracod-bearing sections in the Ballagan Formation in central Scotland. 1, Heads of Ayr coastal section (see Stephenson et al., 2003, fig. 1); 2, Blairmulloch Farm Borehole [National Grid Reference (NGR) NS 56050 28200]; 3, Spilmersford Borehole [NGR NT 4570 6902]; 4, Glenrothes Borehole [NGR NO 25615 03142]; 5, East Dron Borehole [NGR NO 1360 1572].

Nottingham (Kingsley Dunham Centre). Figured specimens are registered with the prefix MPK, whilst faunal slides are prefixed MPA. Rock slab material from the boreholes is stored at BGS Edinburgh (Murchison House). Registration numbers for the borehole rock slabs mentioned in the text are identified by the prefix EV, ET, 11E, 15E or $16 \mathrm{E}$. Where rock slab specimens were accessioned into the Type and Stratigraphical collections they are stored in the museum at Nottingham and are identified by the prefix GSE. BGS Technical Reports on the ostracods in each borehole (Glenrothes, East Dron, Spilmersford, Blairmulloch Farm) and in the Ayrshire coastal section are available through the BGS library at Nottingham: http:// www.bgs.ac.uk and http://geolib.bgs.ac.uk (reports IR/01/031, IR/01/063, IR/02/110, IR/02/194, IR/03/026).

\section{PALAEOENVIRONMENTAL SETTING}

\section{Sedimentology}

The Ballagan Formation was deposited in low-lying coastal floodplains in a semi-arid environment (Andrews et al., 1991; Turner, 1991; Andrews \& Nabi, 1998; Stephenson et al., 2003, 2004a). It is dominated by grey mudstones and siltstones with fine-grained carbonate cements and shelly material. Nodules and thin (generally up to $30 \mathrm{~cm}$ thick) beds of ferroan dolostones 


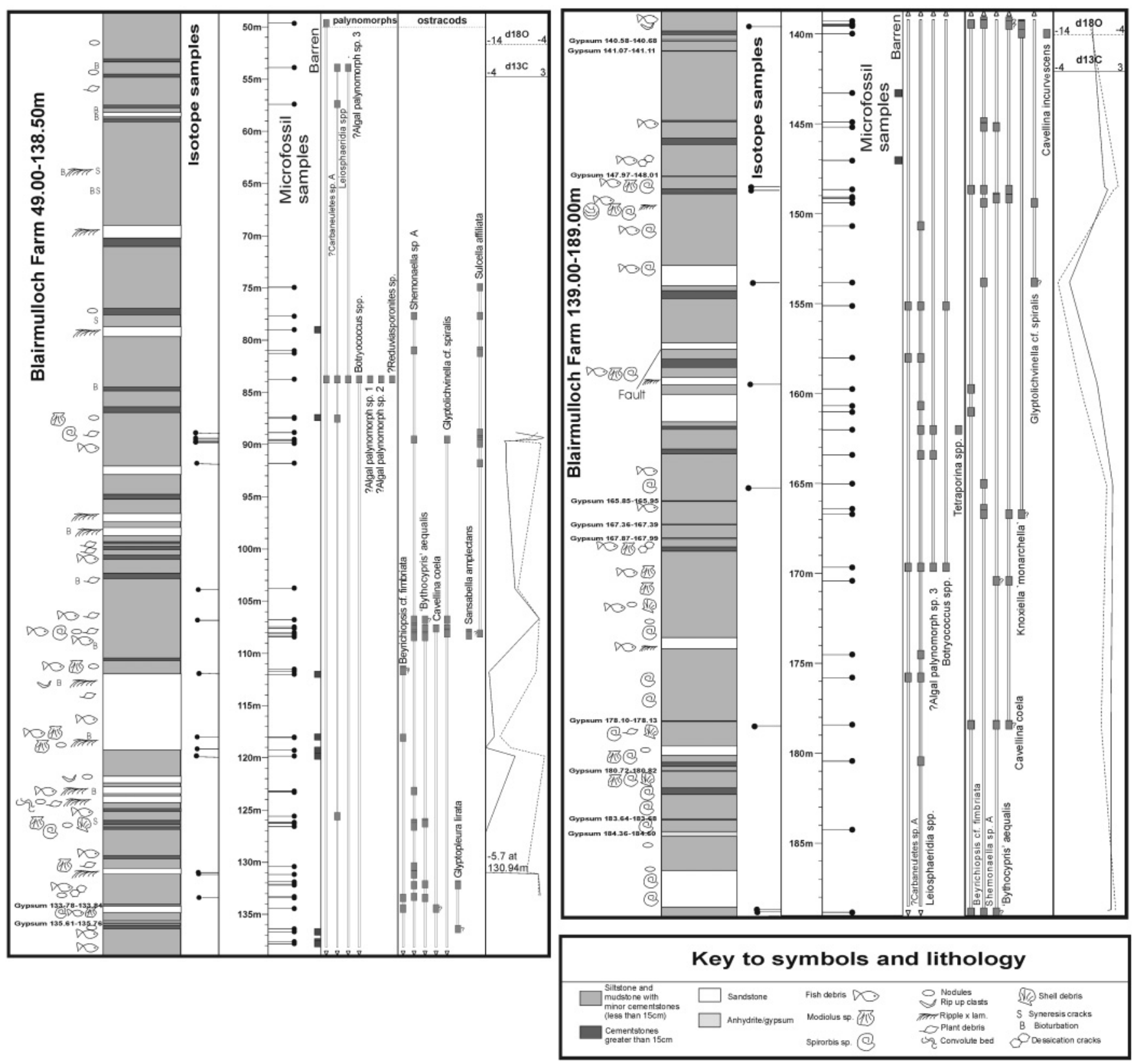

Fig. 3. Sedimentology of the Ballagan Formation in the Blairmulloch Farm Borehole. Further details about the fauna and flora of this borehole can be sourced from Dean (1998) and Stephenson et al. (2004a). The temporal variation in $\delta^{13} \mathrm{C}$ and $\delta^{18} \mathrm{O}$ isotopes is too coarse to resolve any clear stratigraphical trends (spaced at $c .4 \mathrm{~m}$ intervals), though the ratios are indicative of carbonates deposited in brackish (mixed marine + fresh water) salinities (see Fig. 4). Also shown are key palynomorphs.

(the 'cementstones' of earlier terminology) occur. Thin sandstones are widespread geographically. Rootlet beds, thin evaporite horizons (gypsum, anhydrite) and pseudomorphs of halite are associated sometimes with the mudstones (Fig. 3). These finer-grained sediments, which are characterized by desiccation cracks, were probably deposited on a low energy coastal plain in lakes, ponds and lagoons, subject to periodic aridity (Turner, 1991; Stephenson et al., 2003). Sharp-based and ripplelaminated sandstones probably represent distal crevasse splay deposits that were supplied across the floodplain during periodic fluvial flood events.
The thinly bedded calcareous dolostones represent primary dolomite deposited during arid phases, causing conditions of fluctuating salinity and periods of desiccation. Evidence from the $\delta^{18} \mathrm{O}$ and $\delta^{13} \mathrm{C}$ isotope values (below), indicate that lakes and ponds were subject to evaporation and to fresh water input by run-off and rainfall. Incursions of water with normal marine salinity are probably responsible for the rare marine fauna present, such as foraminifer test-linings and brachiopod debris (see also Stephenson et al., 2004a, b).

In the Ayrshire sequence, at the Heads of Ayr (Fig. 2, locality 1), Stephenson et al. (2003) distinguished lithofacies of a tidal 


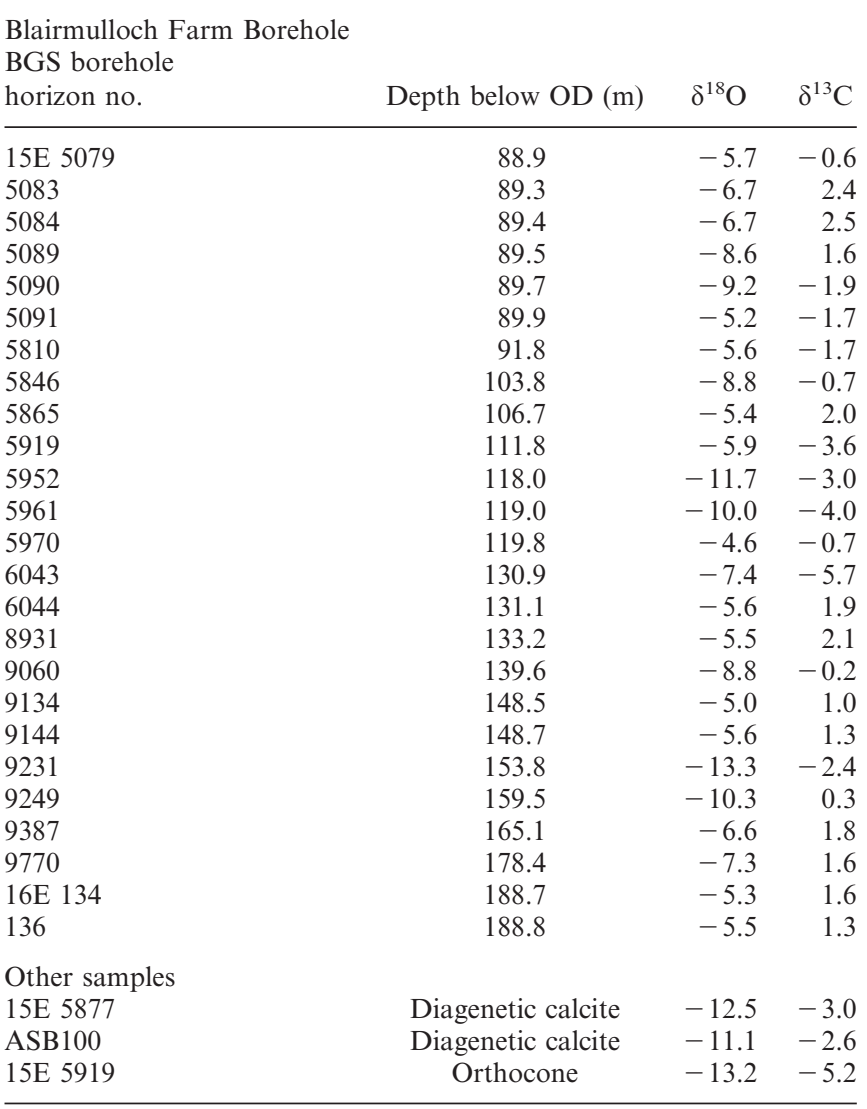

Note: three examples of diagenetic calcite from this sequence are also analysed.

Table 1. Stable isotope data $\left(\delta^{13} \mathrm{C}\right.$ and $\left.\delta^{18} \mathrm{O}\right)$ for carbonates from 25 mudstone samples in the Ballagan Formation of the Blairmulloch Farm Borehole (see Fig. 4).

flat setting, with halite pseudomorphs, mud cracks and carbonaceous (plant) material, succeeded upwards by more lagoonal facies characterized by mudstone-dolostone interbeds. At the top of this sequence are sandstones thought to be of fluvial origin (Stephenson et al., 2003, p. 98). Both the tidal flat and lagoonal facies are ostracod bearing. Elsewhere in the Midland Valley (Fig. 2, localities 2-5) ostracods occur dominantly in mudstone and dolostone sequences, probably deposited in lagoons or brackish lakes on a coastal plain with fluctuating salinities.

\section{$\delta^{13} \mathrm{C}$ and $\delta^{18} \mathrm{O}$ stable isotopes}

Analysis of calcium carbonate for carbon and oxygen isotope ratios (expressed as $\delta^{13} \mathrm{C}$ and $\delta^{18} \mathrm{O}$ ) from 25 carbonate-bearing mudstone samples spread through $100 \mathrm{~m}$ of strata, between depths $88.85 \mathrm{~m}$ and $188.75 \mathrm{~m}$ below Ordnance Datum (OD) in the Blairmulloch Farm Borehole (Fig. 3), provide evidence for the aquatic environment of deposition for the Ballagan Formation (Table 1; see Fig. 4 for methodology). The sequence in this borehole is characterized by interbedded muds, silts and dolostones, with occasional evaporite and sandstone beds. These indicate a quiescent lagoon or lacustrine setting, with fluctuating salinity and periodic desiccation.

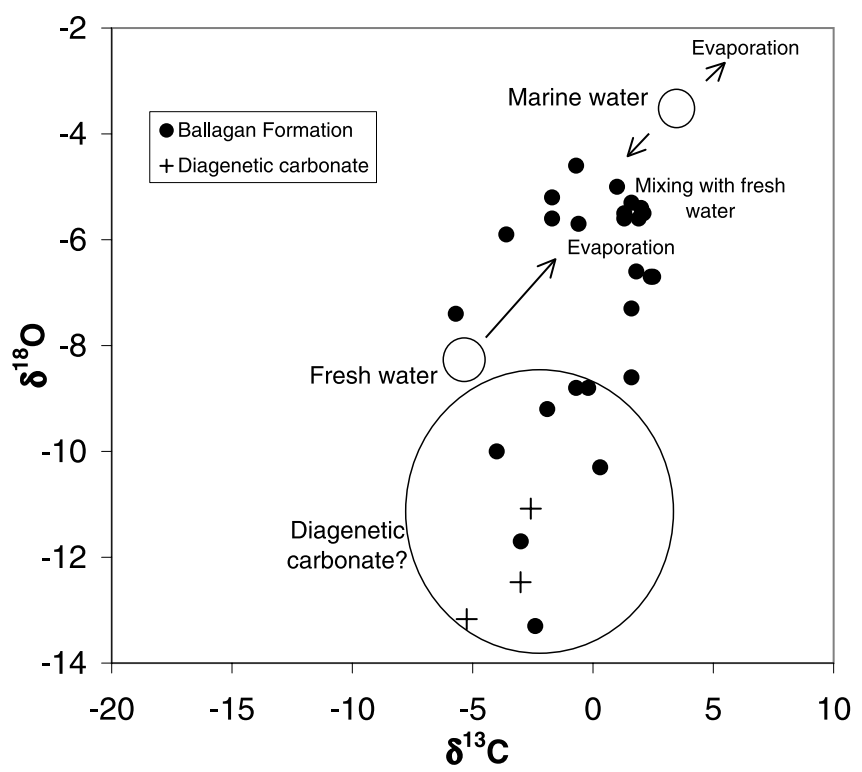

Fig. 4. Stable isotope ratios $\left(\delta^{13} \mathrm{C}\right.$ and $\left.\delta^{18} \mathrm{O}\right)$ of carbonates in 25 mudstone samples from the Ballagan Formation, through about $100 \mathrm{~m}$ of the strata in the Blairmulloch Farm Borehole. Although some of the carbonates yield values in the range of diagenetic carbonate (determined from a recrystallized orthocone test and ostracods with calcite overgrowths; see Table 1), most values suggest evaporated fresh water or a mixture of marine and fresh water (i.e. brackish). There is no normal marine salinity signature $\left(\delta^{18} \mathrm{O}-c .-4 \%\right.$ to $-3 \%$; see Bruckschen et al., 1999) for any of the carbonates analysed. The fields for marine water and fresh water are explained in the text. For stable isotope analysis, mudstones without obvious diagenetic calcite - and avoiding shelly fragments - were ground to a powder and reacted with anhydrous phosphoric acid in vacuo overnight at a constant $25^{\circ} \mathrm{C}$. The $\mathrm{CO}_{2}$ liberated was separated from water vapour under vacuum and collected for analysis. Measurements were made on a VG Optima mass spectrometer. Overall, analytical reproducibility for these samples is normally better than 0.1 for $\delta^{13} \mathrm{C}$ and $\delta^{18} \mathrm{O}(2 \mathrm{~s})$. Isotope values $\left(\delta^{13} \mathrm{C}\right.$, $\left.\delta^{18} \mathrm{O}\right)$ are reported as per mille deviations of the isotopic ratios $\left({ }^{13} \mathrm{C} /{ }^{12} \mathrm{C}\right.$, ${ }^{18} \mathrm{O} /{ }^{16} \mathrm{O}$ ) calculated to the VPDB scale using a within-run laboratory standard calibrated against NBS standards.

The $\delta^{18} \mathrm{O}$ values (to Vienna Pee Dee Belemnite standard, VPDB) of the Ballagan Formation carbonates span a large range from $-13.3 \%$ to $-4.6 \%$. The average European Lower Carboniferous marine carbonate signature is $c$. $-4 \%$ to $-3 \%$ (Brand, 1989; Bruckschen et al., 1999; Veizer et al., 1999). All the oxygen isotope data from the Ballagan Formation are lower than this sea water value, suggesting the sediments analysed were deposited in aquatic settings that did not have normal marine salinity, assuming that sea water was not at a higher temperature or had a lighter $\delta^{18} \mathrm{O}$ and there was no significant recrystallization during burial (cf. Tucker et al., 2003). There are no unequivocal published estimates for Early Carboniferous fresh water $\delta^{18} \mathrm{O}$ in Scotland, although Scotland was part of Pangaea close to the equator (see Mississippian reconstruction of the North Atlantic region by R. C. Blakey available through http://www4.nau.edu/geology/blakey.html) and sea water $\delta^{18} \mathrm{O}$ (the initial source of all fresh water) was much lower than today and at a higher temperature (Bruckschen et al., 1999). These factors suggest meteoric water was probably much lower than current equatorial rainfall $\delta^{18} \mathrm{O}$ (Yurtsever \& Gat, 1981). Indeed, Devonian calcretes thought to have precipitated from 

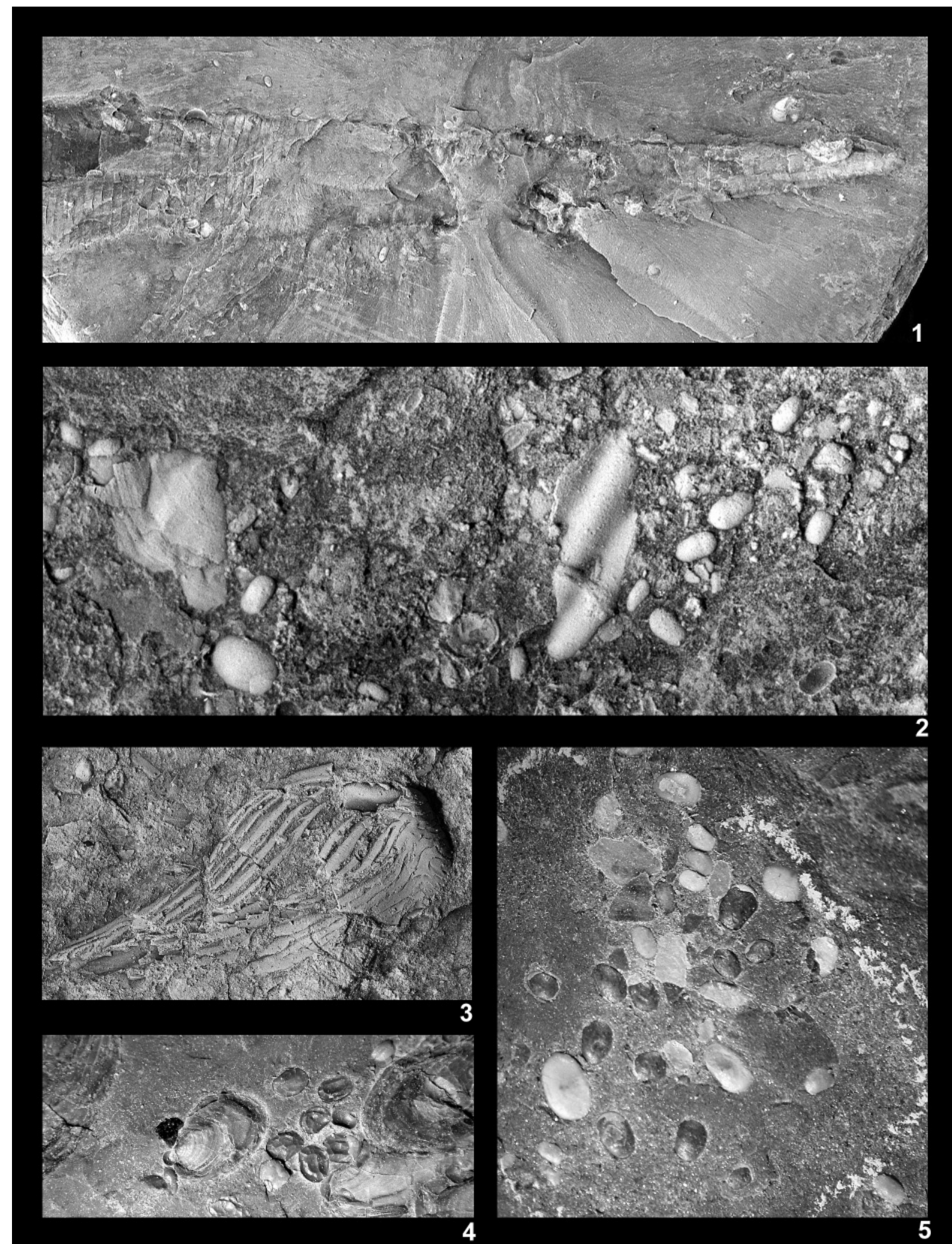

Explanation of Plate 1.

Faunal elements of the Ballagan Formation: 1, ostracods associated with a rare orthocone (GSE15210), colonized by Spirorbis sp. and displaced from its original marine setting prior to burial $(\times 3)$; 2 , Cavellina coela associated with rare brachiopod debris $($ GSE15217) $(\times 14)$; 3 , fish debris (GSE15213) ( × 7); 4, Shemonaella sp. A and Modiolus latus (GSE15212) (×4); 5, well-preserved valves of Shemonaella sp. A (GSE15207) ( $\times 6)$. 
M. Williams et al.
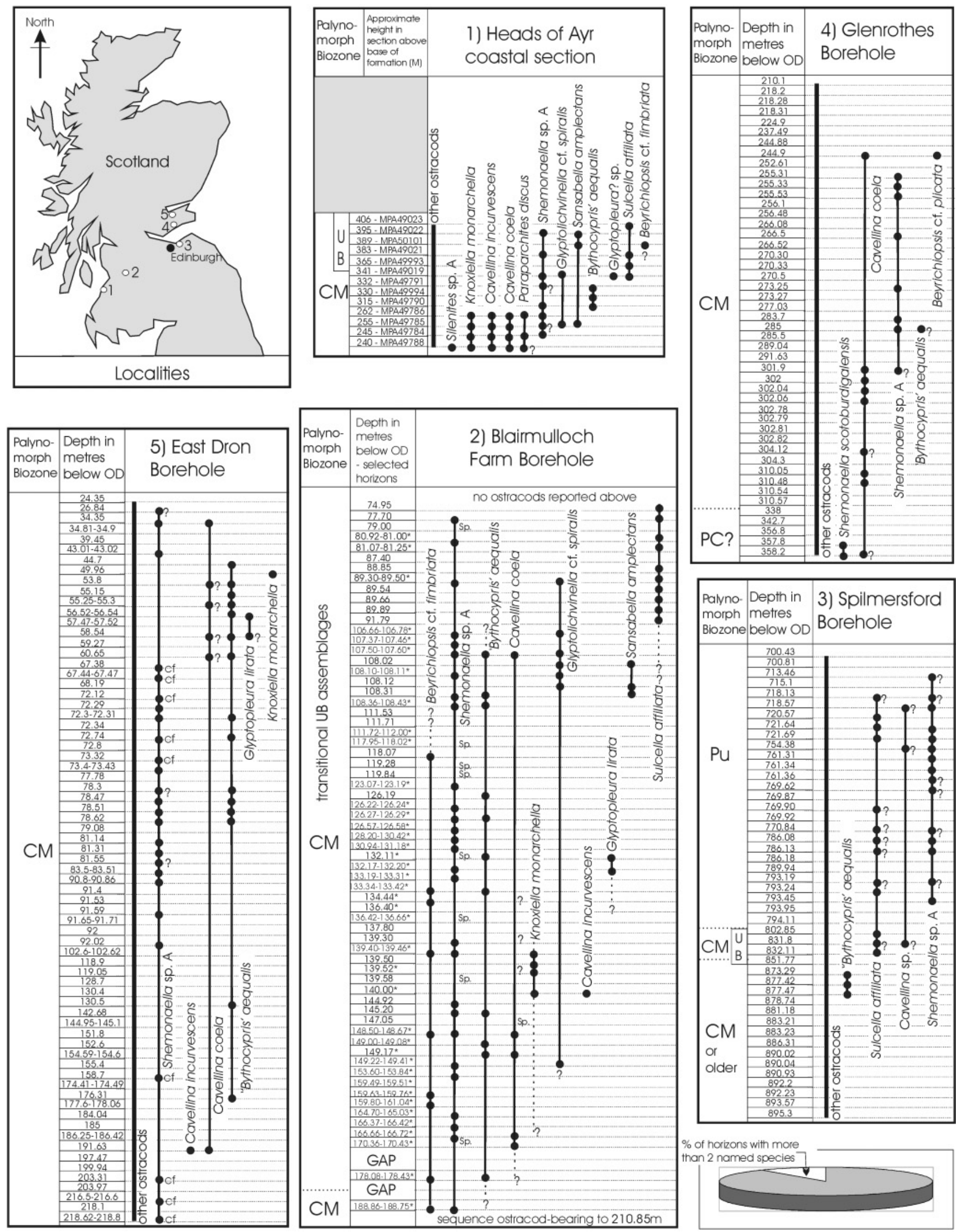
evaporated soil water have been found to have $\delta^{18} \mathrm{O}$ values between $-9.0 \%$ and $-8.0 \%$ (Andrews et al., 1991; Turner, 1991), suggesting that the Early Carboniferous fresh water $\delta^{18} \mathrm{O}$ might have been lower than this. Thus, carbonate $\delta^{18} \mathrm{O}$ values of around $-9 \%$ to $-8 \%$ are probably typical of evaporated fresh waters from rivers entering the coastal environment. Fresh water and marine carbonates are thus thought to have $\delta^{18} \mathrm{O}$ around $-9 \%$ and $-3 \%$, respectively. Values between $-9 \%$ and $-3 \%$ are, therefore, either evaporated fresh water (which increases $\left.\delta^{18} \mathrm{O}\right)$ or a mixture of fresh water and sea water $\left(\delta^{18} \mathrm{O} c .-3 \%\right.$. There are no samples that have $\delta^{18} \mathrm{O}$ values around the expected value for sea water. However, there are some samples with $\delta^{18} \mathrm{O}$ values that are very low. Two samples of diagenetic calcite overgrowths adhering to ostracod carapaces (see Table 1) and also a sample of recrystallized orthocone gave low $\delta^{18} \mathrm{O}$ $(-13.2 \%$ to $-11.1 \%$ ) , suggesting that the carbonate with low $\delta^{18} \mathrm{O}(<-9 \%)$ in the sediments may have had secondary fluids passing through them which precipitated calcite via dissolution and re-equilibration during burial and diagenesis. These low values may be a function of recrystallization at higher temperatures during burial, although there is no evidence for low-grade metamorphism.

The $\delta^{13} \mathrm{C}$ values (to VPDB) of the Ballagan Formation carbonates analysed span a range between $-5.7 \%$ to $+2.5 \%$ (Fig. 4), lower than Early Carboniferous sea water, which had a $\delta^{13} \mathrm{C}$ value of $+3 \%$ o to $+4 \%$ o (Bruckschen et al., 1999). Fresh water $\delta^{13} \mathrm{C}$ tends to be derived from $\mathrm{CO}_{2}$ via soils and has low $\delta^{13} \mathrm{C}$. Modern groundwaters in Europe have $\delta^{13} \mathrm{C}$ of $-10 \%$ to - 15\% (Andrews et al., 1997). This can be modified to higher values by a number of processes (Leng \& Marshall, 2004), including exchange with atmospheric $\mathrm{CO}_{2}$ in evaporating waters and mixing with heavier marine $\delta^{13} \mathrm{C}$. In localized environments - for example, in organic-rich environments - oxidation of organic matter can lead to low $\delta^{13} \mathrm{C}$. In the Ballagan Formation the preservation of large amounts of organic matter in the sediments analysed suggests that there may have been preferential utilization of the lighter isotope, thus causing the resultant carbonate minerals precipitating to have high $\delta^{13} \mathrm{C}$. All of these processes might have been occurring during deposition of the Ballagan Formation, although the $\delta^{18} \mathrm{O}$ data suggest that the sediments analysed were deposited in evaporating fresh water or a mixed fresh water-marine (i.e. brackish) environment.

\section{Palaeontology}

The ostracod fauna of the Ballagan Formation is dominated numerically by paraparchitaceans, though platycopes, palaeocopes and podocopes are well represented. Ostracod assemblages with this range of taxonomic groups are known from brackish water, supratidal and shelf environments in the Carboniferous (Dewey et al., 1990). Although ostracods occur in the dolostones (Turner, 1991), most ostracod-bearing horizons are grey-green mudstones and silty mudstones. The overall environment of deposition, dominated by muds, suggests low energy (Fig. 3). This notion is supported by the size distribution of the ostracods in the assemblages, which often encompass juveniles and adults (particularly in paraparchitaceandominated assemblages), and the preservation of the valves and carapaces - some in 'butterfly' orientation - which also suggests that many assemblages preserve original biocoenoses (Pl. 1, figs 4, 5). Nevertheless, in the East Dron Borehole the ostracods often occur in thin shell lags in mudstone sequences, suggesting that they have been transported, though the size distribution (adults and juveniles), good preservation of the ostracod valves and occurrence of the same ostracods more thinly scattered on adjacent mudstone laminae, suggests that this was only local. Some assemblages, for example those of Cavellina coela occurring with rare brachiopod debris, suggest wider transport and are dominated by adult and sub-adult valves, suggesting sorting (Pl. 1, fig. 2).

The co-occurrence of the bivalve Modiolus with the ostracods (P1. 1, fig. 4; Fig. 3), the low-diversity of the assemblages typically one to five species per horizon - though about $90 \%$ of horizons have no more than two named species (Fig. 5), the absence of normal marine salinity faunas such as corals or echinoderms, and the associated sediments all suggest aquatic settings that were not normal marine salinity. At many horizons the ostracods, particularly $C$. coela and the paraparchitaceans Shemonaella and Paraparchites, are associated with halite pseudomorphs, calcretes and mud-cracks, suggesting that they tolerated elevated salinity (hypersaline) environments in ephemeral bodies of water (Stephenson et al., 2003, 2004a). Some ostracod-bearing horizons are reddened, suggesting post-depositional subaerial oxidation. Diminutive ostracods sometimes occur in calcrete-bearing horizons and in mudstones adjacent evaporites. A quasi-marine or brackish water setting is also suggested by the common occurrence of plant fragments sometimes several centimetres long, calcareous worm tubes of Spirorbis, conchostracans and Naiadites trace fossils. Very rare (four horizons from several hundred studied) co-occurrences of ostracods (Cavellina coela) with fragmentary brachiopod valves and orthoconic nautiloids (some colonized by Spirorbis) indicate limited normal marine influence (Pl. 1, figs 1, 2), possibly through flooding of coastal floodplains and lagoons by sea water during storm events. Nevertheless, there is no evidence for marine bands with a normal marine salinity fauna at any level in the Ballagan Formation that the authors have examined. Most telling in this respect is the absence of corals, echinoderms, goniatites, in situ (i.e. complete and undisturbed) brachiopods or conodonts. The absence of typical stenohaline marine ostracods such as Bairdia and Amphissites, which characterize open marine biotopes (Becker \& Bless, 1990; Dewey \& Puckett, 1993), also concurs with the sedimentological interpretation of the Ballagan Formation as a coastal floodplain. Beyrichiaceans, reported from nearshore Early Carboniferous environments in Atlantic Canada (Tibert \& Scott, 1999), are also absent from the Ballagan Formation. Furthermore, palynological evidence from the Ballagan Formation also supports brackish-water settings (e.g. Fig. 3). There are no marine acritarchs in the Ballagan

Fig. 5. Stratigraphical distribution of ostracods in the Ballagan Formation at five key sections (localities as Fig. 2). The ranges are calibrated with the palynomorph biozones (see Stephenson et al., 2003, 2004b). 'UB' denotes 'upper Ballagan' palynomorph assemblages of Stephenson et al. (2003). Sulcella affiliata has a consistent late CM Biozone first occurrence in three sections (1-3). Several species have earlier ranges than recorded previously (Robinson, 1978), including 'Bythocypris' aequalis and Glyptopleura lirata. Some of the 'horizons' are composites of several adjacent laminae. 


\begin{tabular}{|c|c|c|c|c|c|c|c|c|c|c|c|c|c|c|c|}
\hline \multicolumn{2}{|c|}{ Ostracod species } & \multirow[t]{2}{*}{1} & \multirow[t]{2}{*}{2} & \multirow[t]{2}{*}{3} & \multirow[t]{2}{*}{4} & \multirow[t]{2}{*}{5} & \multirow[t]{2}{*}{6} & \multirow[t]{2}{*}{7} & \multirow[t]{2}{*}{8} & \multirow[t]{2}{*}{9} & \multirow[t]{2}{*}{10} & \multirow{2}{*}{$\frac{11}{X}$} & \multirow[t]{2}{*}{12} & \multirow{2}{*}{$\frac{13}{X}$} & \multirow[t]{2}{*}{14} \\
\hline 1 & Glyptopleura lirata & & & & & & & & & & & & & & \\
\hline 2 & Cavellina coela & & & $\mathrm{X}$ & ? & $\mathrm{X}$ & $\mathrm{X}$ & $\mathrm{X}$ & $\mathrm{X}$ & $\mathrm{X}$ & $\mathrm{X}$ & $\mathrm{X}$ & ? & $\mathrm{X}$ & $\mathrm{X}$ \\
\hline 4 & Sulcella affiliata & & $?$ & & & $\mathrm{X}$ & & $?$ & & & & $\mathrm{X}$ & $\mathrm{X}$ & & $\mathrm{X}$ \\
\hline 5 & Glyptolichvinella $\mathrm{cf}$. spiralis & & $\mathrm{X}$ & & $\mathrm{X}$ & & & $\mathrm{X}$ & & & & $\mathrm{X}$ & & & $\mathrm{X}$ \\
\hline 6 & Knoxiella monarchella & & $\mathrm{X}$ & $\mathrm{X}$ & & & & & $\mathrm{X}$ & & $\mathrm{X}$ & $\mathrm{X}$ & & & $\mathrm{X}$ \\
\hline 10 & Paraparchites discus & & $\mathrm{X}$ & $\mathrm{X}$ & & & $\mathrm{X}$ & & & & & $\mathrm{X}$ & & & $\mathrm{X}$ \\
\hline 11 & Shemonaella sp. A & $\mathrm{X}$ & $\mathrm{X}$ & $\mathrm{X}$ & $\mathrm{X}$ & $\mathrm{X}$ & $\mathrm{X}$ & $\mathrm{X}$ & $\mathrm{X}$ & & $\mathrm{X}$ & & & $\mathrm{X}$ & \\
\hline 12 & Shemonaella scotoburdigalensis & & $?$ & & $\mathrm{X}$ & & & & & & & & & & \\
\hline 13 & 'Bythocypris' aequalis & $\mathrm{X}$ & $\mathrm{X}$ & & & & & $\mathrm{X}$ & $\mathrm{X}$ & & & $\mathrm{X}$ & & & \\
\hline 14 & Silenites sp. A & & $\mathrm{X}$ & $\mathrm{X}$ & $\mathrm{X}$ & $\mathrm{X}$ & $\mathrm{X}$ & & & & $\mathrm{X}$ & & & & \\
\hline
\end{tabular}

Certain species, particularly Shemonaella sp. A and Cavellina coela, occur with a spectrum of faunal associates and may have been eurytopic.

Table 2. Co-occurrence of ostracods in the Ballagan Formation.

Formation (Stephenson et al., 2004a). Instead, the microflora is dominated by the spores of land plants from the hinterland and by indigenous aquatic algae such as Botryococcus. These algae include non-hapotypic taxa that suggest low salinity ecologies (Stephenson et al., 2004a).

Although most of the ostracod species of the Ballagan Formation co-occur (Table 2) and, therefore, may have possessed overlapping ecologies, or at least were transported into adjacent ecologies, certain ostracods may have favoured particular aquatic settings during deposition of the Ballagan Formation, perhaps influenced by fluctuating salinity (from brackish to hypersaline). Some taxa, such as Cavellina coela and Shemonaella sp. A occur across a spectrum of ostracod assemblages and may have been eurytopic (Fig. 5, Table 2). In the Early Carboniferous of Atlantic Canada, Tibert \& Scott (1999) were able to distinguish five marginal marine through coastal marsh assemblages, four of which are ostracod bearing. Their assemblages include shallow nearshore glauconite-bearing mudstones and hummocky cross-stratified sandstones, fully marine facies that are not present in the Ballagan Formation. In a provisional study of the Ballagan Formation fauna and flora, Stephenson et al. (2003) identified three ostracod assemblages in Ayrshire, based on presence-absence data and a semiquantitative assessment of the most common elements of the ostracod faunas at each horizon. Their assemblages occupy lithofacies of supratidal-tidal flat ecologies, and brackish and low-salinity lagoons. These assemblages can also be recognized in Ballagan Formation sequences across the Midland Valley (Williams, 2002). The supratidal-tidal flat assemblage of Stephenson et al. (2003) is associated with halite pseudomorphs and mud-crack horizons in Ayrshire and forms the most diverse assemblages with up to five species occurring at some horizons. It comprises Cavellina coela, $C$. incurvescens, Knoxiella monarchella sp. nov., Paraparchites discus sp. nov., Silenites sp. (referred to as Bairdia cf. jakutika by Stephenson et al., 2003) and Shemonaella sp. A. Paraparchitaceans and cavellinids are dominant. The identification by Stephenson et al. (2003) of Acratia sp. in this assemblage is based on a fragmentary valve, which is indeterminate. These ostracods sometimes occur with Spirorbis worm tubes, modern representatives of which are regarded as eurytopic (Hantzschel 1975, fide Tibert \& Scott, 1999).
Stephenson et al. (2003) also identified a possible brackishwater lagoonal ostracod assemblage in the Ballagan Formation of Ayrshire, characterized by 'Bythocypris' aequalis. This environmental interpretation is supported by the occurrence of zygnematacean algae and Botryococcus in these assemblages, both of which, in modern ecologies, are restricted to fresh- and brackish-water settings, and by the associated sediments, which comprise mudstone-dolostone interbeds. In the East Dron Borehole this assemblage is recognized by bispecific assemblages of 'B.' aequalis and Shemonaella sp. A, associated with the bivalve Modiolus latus at more than 15 horizons (see Pl. 1, fig. 4). The latter is regarded generally as having wide environmental tolerance from marginal marine to brackish-water (Wilson in Lumsden et al., 1967, p. 90; Wilson, 1989, p. 103). Beyrichiopsis cf. fimbriata is also sometimes associated with these assemblages (Fig. 5) and can crowd lamination surfaces, for example in the Blairmulloch Farm Borehole. In his analysis of ostracod faunas from Maritime Canada, Dewey (1983) considered 'B.' aequalis to be associated with brackish marine water. Shemonaella sp. A. often dominates horizons in the Ballagan Formation of the East Dron Borehole to the exclusion of other ostracods. It may have been able to withstand raised salinities or water chemistries that excluded other ostracods: low-diversity 'paraparchitacean assemblages' are often associated with hypersaline ecologies (Dewey, 1987, 2001; Dewey \& Puckett, 1993).

Stephenson et al. (2003) noted a third ostracod assemblage in Ayrshire, characterized by the platycope Sulcella affiliata, often in monospecific assemblages (Fig. 5). This assemblage is possibly a temporal successor to the brackish-water/lagoonal faunas dominated by 'B.' aequalis and Shemonaella sp. A earlier in the sequence and occurs, for example, in the upper part of the Ballagan Formation of the Blairmulloch Farm Borehole (Figs 3, 5). Sulcella affiliata occurs with algal palynomorphs, including Botryococcus, which signal low-salinity (brackish?) conditions (Stephenson et al., 2003, 2004a). This species also occurs with Sansabella amplectans and Glyptolichvinella cf. spiralis. Both of these species were accorded a brackish 'carbonaceous facies' tolerance by Robinson (1978). Dewey et al. (1990) and Dewey \& Puckett (1993) also record Sansabella in nearshore and brackishwater environments, where it is a representative of the 'kloedenellacean assemblage', influenced by lower salinity 


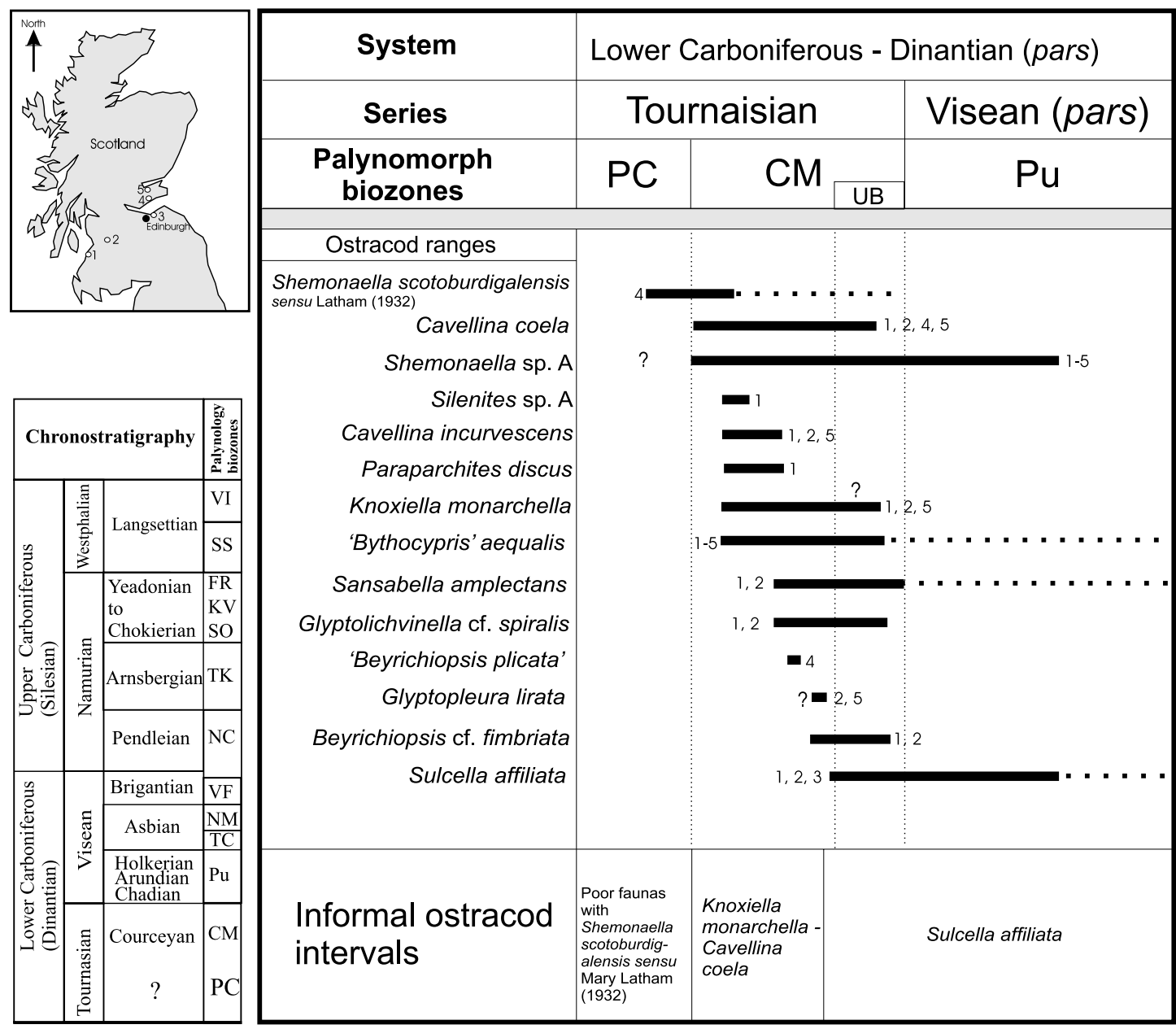

Fig. 6. Composite range chart for ostracods of the Ballagan Formation, reconstructed from data in Figure 5. The numbers against each range indicate the locality source of the data. The inset time-scale shows the position of the studied sequence within the Carboniferous. A dotted line on the range chart indicates that a species has a longer recorded range elsewhere. 'UB' denotes 'upper Ballagan' palynomorph assemblages of Stephenson et al. (2003).

(Dewey, 2001). In Ayrshire and in the Spilmersford Borehole, faunas with $S$. affiliata often occur within the sandy infillings of mud cracks - many bearing wind-blown 'millet-seed' sand grains, suggesting colonization of ephemeral water bodies.

\section{BIOSTRATIGRAPHY}

Throughout the Midland Valley of Scotland much of the Ballagan Formation yields palynomorph assemblages of the CM Biozone of the Tournaisian (e.g. Stephenson et al., 2003, 2004b and references therein), though in some areas the formation may be of earliest Carboniferous PC Biozone age, and elsewhere extends into the $\mathrm{Pu}$ Biozone of the Early Viséan (Stephenson et al., 2003, 2004b). The stratigraphical distribution of ostracods in the Ballagan Formation is reconstructed from assemblages at five key sections (Fig. 5) and is calibrated with the established palynomorph biostratigraphy (Stephenson et al., 2003, 2004b and references therein). The overall ranges of species appear to be controlled by factors other than long duration changes in palaeoenvironment, such as a switch from coastal floodplain to shallow-marine shelf, a transition that only occurred later in the Dinantian of Scotland (Lower Limestone Formation; see
Fig. 1). Some ostracod species emerge as useful local proxies for the palynomorph biozones (Fig. 6). Shemonaella scotoburdigalensis sensu Latham (1932) appears early in the sequence, possibly in the PC Biozone. However, the biostratigraphical utility of this species is limited, as $S$. scotoburdigalensis is recorded from younger strata elsewhere (e.g. see Robinson, 1978) and, in addition, specimens referred to this species show a range of shape variation that might encompass more than one species. The new species Knoxiella monarchella has an overall stratigraphical range similar to the CM palynomorph Biozone in the Midland Valley and is a useful proxy for that interval, though its stratigraphical occurrence is intermittent. Also appearing in the lower part of the CM Biozone are 'Bythocypris' aequalis, Cavellina coela, C. incurvescens, Sansabella amplectans and Shemonaella sp. A. The new species Paraparchites discus may be limited to the lower-middle part of the CM Biozone, though it is so far known only from the Heads of Ayr section in Ayrshire. Sulcella affiliata appears consistently near the top of the CM Biozone and its first appearance is not associated with a change in facies (Fig. 3). It enables a local upper subdivision of the CM Biozone, particularly as the incoming of $S$. affiliata 


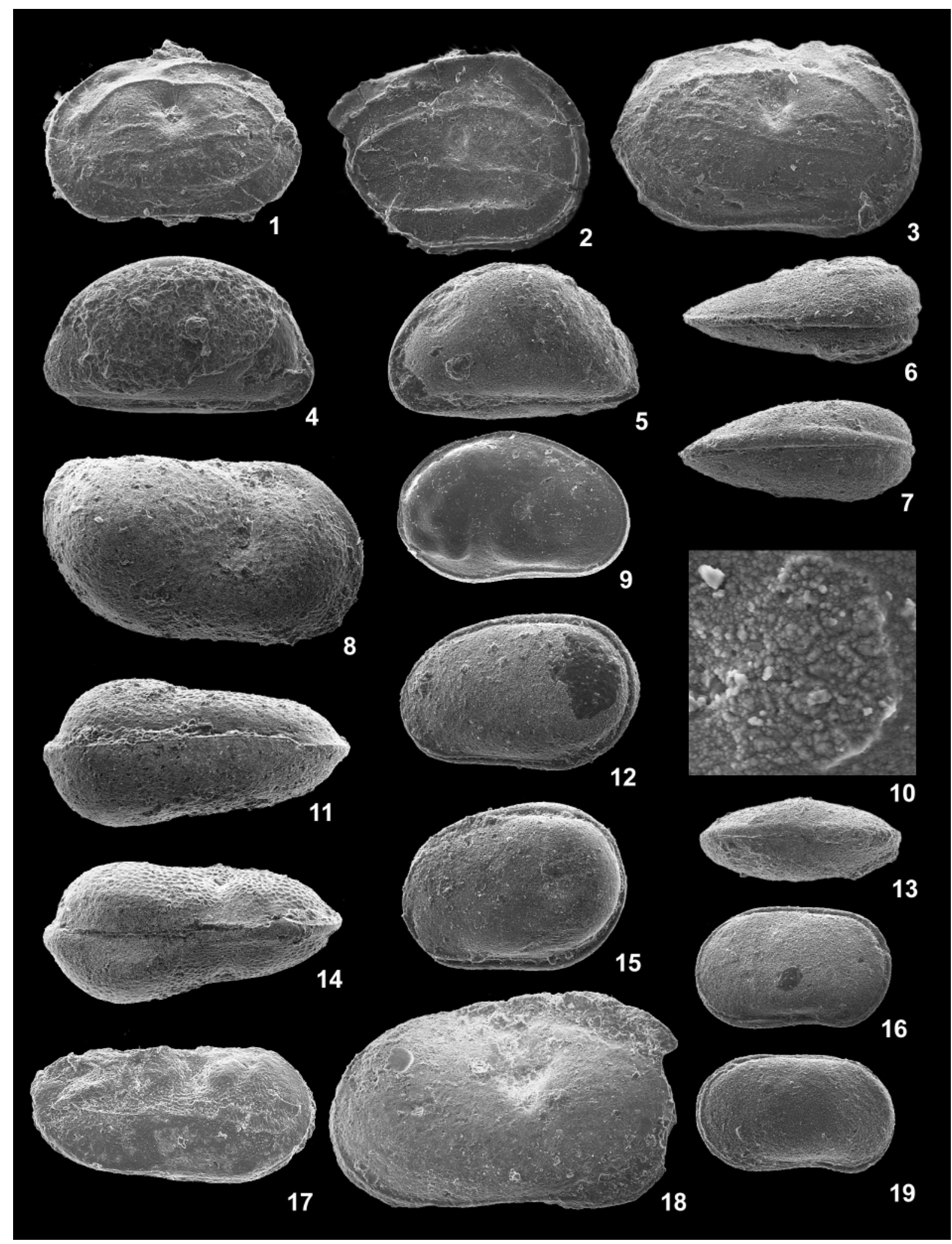


appears to correlate closely with 'Upper Ballagan' palynomorph assemblages from Ayrshire (Stephenson et al., 2003). This provides for a more precise correlation of rock sequences over several tens of kilometres in central Scotland (Stephenson et al., 2004b).

The ranges of many ostracod species are consistent with those depicted by Robinson (1978). However, the new records refine the distribution of several Carboniferous ostracod species, such that ' $B$.' aequalis, $S$. affiliata, $G$. lirata and $S$. amplectans are confirmed for the first time from pre-Viséan horizons in Britain (Fig. 6).

\section{TAXONOMIC NOTES}

Many Scottish Carboniferous ostracod species have remained unstudied since the work of Mary Latham in 1932. Most have not been redescribed or figured since the 1890s, and the type material of early workers such as T. R. Jones \& J. W. Kirkby (e.g. 1879, 1886a, b, 1896) remains to be re-evaluated. A detailed taxonomic study of this material is beyond the scope of this paper, but this section provides taxonomic notes with illustrations in Plates 2 and 3 of all the key species. Formal descriptions of Knoxiella monarchella sp. nov. and Paraparchites discus sp. nov. are given in the Systematic Palaeontology section. Registered specimens in the BGS collections for the ostracods are given in Table 3. Podocopa is used in the sense of Horne et al. (2002). Higher taxonomic groups largely follow the usage of Olempska (1999). References for suprafamilial taxa are not included.

\section{Platycopida Sars}

Four species of platycopids are present in the Ballagan Formation, Cavellina coela (Rome, 1973), C. incurvescens (Jones \& Kirkby, 1896), Sulcella affiliata (Jones \& Kirkby, 1886a) and Glyptolichvinella cf. spiralis (Jones \& Kirkby MS, in Jones, 1885).

Heteromorph carapaces of Cavellina coela (P1. 2, figs 6, 7, 9, $10,12,15)$ have the domicilium expanded posteriorly to produce numerous egg receptacles ( $\mathrm{Pl} .2$, figs 6, 7, 9). Internally, heteromorphs have a well-developed limen demarcating the anterior end of the domatium. At least one specimen preserves a welldeveloped sub-circular muscle scar, situated just anterior of the limen, and comprising numerous $(11+)$ closely set individual scars (Pl. 2, fig. 10). This is similar to the 'primitive' aggregate muscle scar patterns described from other Cavellina species (Olempska, 1999). Cavellina coela differs from its contemporary, Cavellina incurvescens, by its greater size and subovate lateral shape and by the posterior inflation of its carapace in heteromorphs.
Heteromorph carapaces of Sulcella affiliata (Pl. 2, fig. 18) are also inflated posteriorly and possess numerous (more than 7) receptacles for eggs (see Stephenson et al., 2004b, fig. 9). These are disposed in a similar manner to that of $C$. coela and the species of Glyptolichvinella described by Lundin (1987) and Lundin \& Visintainer (1987). Some juveniles of S. affiliata resemble Sulcella cf. indistincta (Tschigova) sensu Robinson (1978), a taxon considered typical of the Tournaisian.

Glyptolichvinella cf. spiralis (Pl. 2, figs 1-3) has a variable number of costae on the lateral surface of its valves: some specimens have only a single costa ventral of the adductorial sulcus (Pl. 2, figs 2, 3), others possess two (Pl. 2, fig. 1). Sometimes both of these costae are disposed ventral of the adductorial sulcus, and sometimes the upper costa intersects the sulcus at about its mid-height. Unlike typical G. spiralis (see Robinson, 1978, pl. 5, fig. 4), and ?G. annularis (Kummerow) of Robinson, 1978, the ridge that forms a loop on the lateral valve surface of $G$. cf. spiralis is continuous. The differences in costate morphology between $G$. cf. spiralis and the typical G. spiralis may be intraspecific, but this requires examination of more material: Lundin's (1987) detailed description of G. spiralis was based on seven available specimens.

\section{Palaeocopida Henningsmoen}

Four species of palaeocopids are present in the Ballagan Formation, Beyrichiopsis cf. fimbriata Jones \& Kirkby, 1886b, Glyptopleura lirata Robinson, 1978, Sansabella amplectans Roundy, 1926 and Knoxiella monarchella sp. nov. Some specimens resembling Beyrichiopsis plicata Jones \& Kirkby may represent a fifth species (see below). Knoxiella monarchella sp. nov. is described in the Systematic Palaeontology section. Although placed here in the Palaeocopida, these straight-hinged taxa may be related closely to the platycopids described above. They all possess domiciliar dimorphism, with posterior inflation of the heteromorph carapace.

The upper size-range of Beyrichiopsis cf. fimbriata (Fig. 7, P1. 2, fig. 17) is similar to those B. fimbriata figured by Robinson (1978, pl. 3, fig. 2a-d). However, unlike the typical B. fimbriata, which possess three costae, in the material from the Ballagan Formation the majority of specimens possess only a single costa, situated below the adductorial sulcus and fully developed in specimens over $1 \mathrm{~mm}$ long (Fig. 7). At least one poorly preserved carapace does show two costae, the second developed towards the dorsal margin (Pl. 2, fig. 17). Some of Jones \& Kirkby's (1886b, pls 11 and 12) figured specimens of $B$. fimbriata also appear to show a reduced number of costa.

Robinson's (1978, p. 136) figured holotype of Glyptopleura lirata (P1. 3, fig. 9) is $1.39 \mathrm{~mm}$ long and the paratype $1.41 \mathrm{~mm}$

Explanation of Plate 2.

Scanning electron micrographs of platycopid and palaeocopid ostracods from the Ballagan Formation. figs 1-3. Glyptolichvinella cf. spiralis (Jones \& Kirkby) (all × 49): 1, right valve, lateral view, MPK13081; 2, incomplete left(?) valve, lateral view, MPK13085; 3, carapace, left lateral view, MPK13078. figs 4, 5. Silenites sp. A: 4, carapace, left lateral view, MPK12457, $\times 52$; 5, carapace, left lateral view, MPK12458, $\times 54$. figs 6, 7, 9, 10, 12, 15. Cavellina coela (Rome, 1973): 6, heteromorph carapace, ventral view, MPK12453, $\times 51$; 7, heteromorph carapace, ventral view, MPK12454, $\times 57 ; \mathbf{9}, \mathbf{1 0}$, heteromorph left valve, internal view and close-up of muscle scar, MPK13076 $(9, \times 49 ; 10, \times 500)$; 12, heteromorph carapace, left lateral view, MPK12455, $\times 55 ; \mathbf{1 5}$, heteromorph carapace, left lateral view, MPK12456, $\times 54$. figs 8, 11, 14. Knoxiella monarchella sp. nov.: 8, holotype, heteromorph right valve, MPK12455, $\times 55 ; \mathbf{1 1}$, heteromorph carapace, ventral view, MPK12466, $\times 56$; 14, heteromorph carapace, dorsal view, MPK12477, $\times 55$; figs 13, 16, 19. Cavellina incurvescens (Jones \& Kirkby, 1896): 13, carapace, ventral view, MPK12460, $\times 55$; 16, carapace, left lateral view, MPK12459, $\times 52$; 19, carapace, left lateral view, MPK12482, $\times 52$. fig. 17. Beyrichiopsis cf. fimbriata (Jones \& Kirkby, 1886b), right valve, lateral view, BGS MWL7176, × 48. fig. 18. Sulcella affiliata (Jones \& Kirkby, 1886a), left valve, lateral view, MPK13080, $\times 49$. 


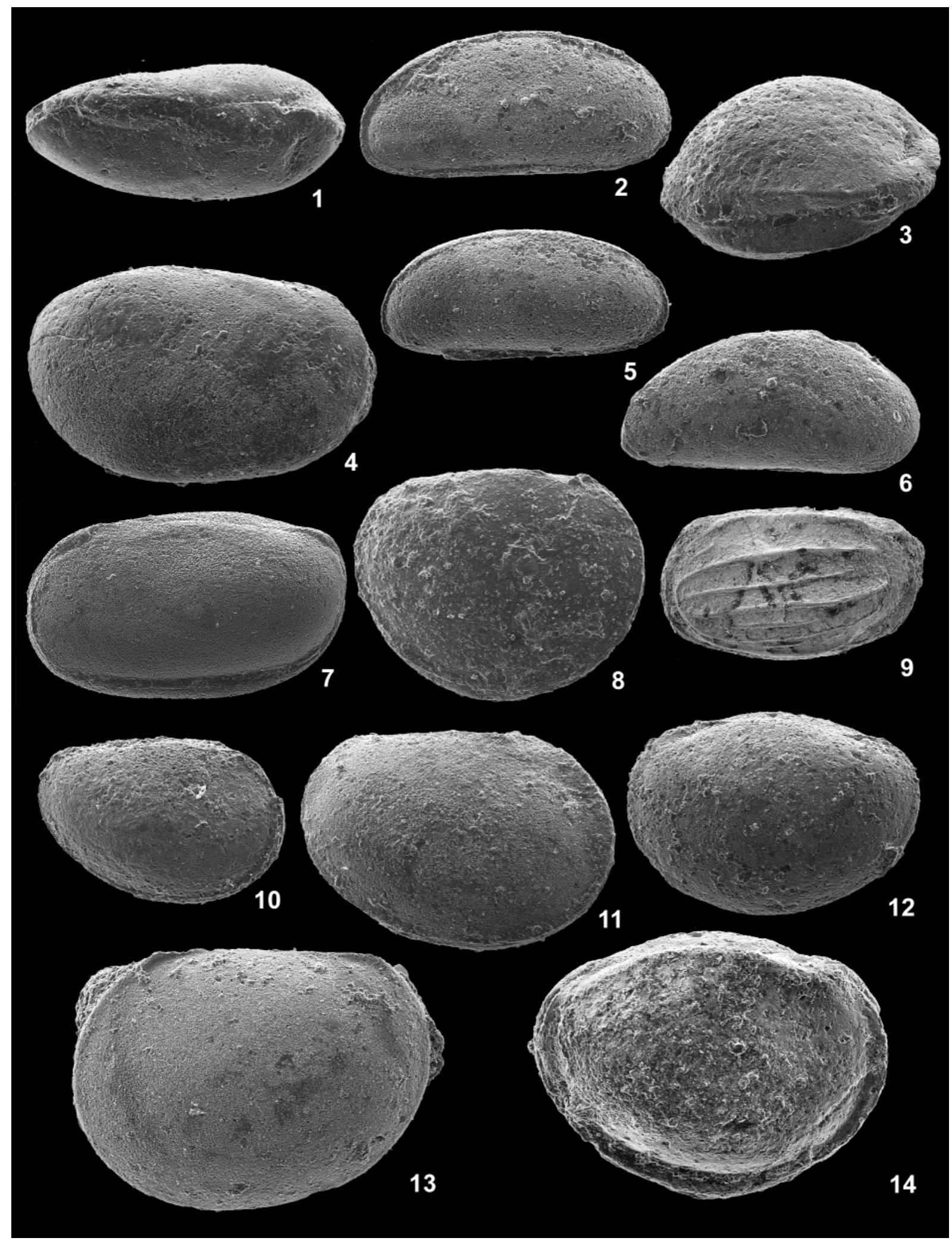


Early Carboniferous ostracods from Scotland

\begin{tabular}{|c|c|c|}
\hline Ostracod species & Section & Material \\
\hline \multirow[t]{3}{*}{ Cavellina coela } & Ayrshire & MPA49784-49786, MPA49788, MPA49708, MPA49709, MPK12543-12456 \\
\hline & Blairmulloch Farm & GSE15162-15164 \\
\hline & Glenrothes & MPA50237, MPA50231; horizons 11E5910, 11E5890-11E5984 \\
\hline \multirow[t]{2}{*}{ Cavellina incurvescens } & Ayrshire & MPK12459, MPK12460, MPK12482, MPA49784-49786, MPA49788 \\
\hline & East Dron & horizon EV2685 \\
\hline Sulcella affiliata & Spilmersford & horizons ET1495, ET1497, ET1498, ET1531 \\
\hline \multirow{2}{*}{ Glyptolichvinella cf. spiralis } & Ayrshire & MPA49019, MPA49785 \\
\hline & Blairmulloch Farm & $\begin{array}{l}\text { GSE15178, GSE15182-15191, GSE15224, GSE15225; MPA52105, MPA52109, } \\
\text { MPA52112, MPK13078, MPK13079, MPK13081, MPK13085 }\end{array}$ \\
\hline Beyrichiopsis cf. fimbriata & Blairmulloch Farm & $\begin{array}{l}\text { GSE15192-15196, GSE15226-15228, GSE15229, GSE15221, BGS MWL7176, BGS } \\
\text { MWL7177 }\end{array}$ \\
\hline \multirow{2}{*}{ Knoxiella monarchella } & Blairmulloch Farm & GSE15162, GSE15165, GSE15201-15204 \\
\hline & East Dron & horizon EV2448 \\
\hline \multirow{2}{*}{ Sansabella amplectans } & Ayrshire & MPA49022, MPA49685, MPA50101, MPK12475 \\
\hline & Blairmulloch Farm & GSE15230, GSE15205; MPA52110, MPK13086 \\
\hline Paraparchites discus & Ayrshire & MPA49784, MPA49786, MPK12449-12451, MPK12461, MPK12464 \\
\hline Shemonaella scotoburdigalensis & Glenrothes & MPA50237, MPA50641, MPK13082, MPK13083 \\
\hline \multirow{5}{*}{ Shemonaella sp. A } & Blairmulloch Farm & e.g. GSE15231-15235 \\
\hline & East Dron & GSE15206, GSE15207, GSE15212 and many more horizons \\
\hline & Glenrothes & e.g. horizon 11E5861 \\
\hline & Spilmersford & e.g. horizon ET1494 \\
\hline & Ayrshire & $\begin{array}{l}\text { e.g. MPA49791, MPA49784, MPA49019, MPA49022, MPK12462, MPK12463, } \\
\text { MPK12470-12473, MPK12477 }\end{array}$ \\
\hline Silenites sp. A & Ayrshire & MPA49788, MPK12457, MPK12458 \\
\hline
\end{tabular}

For further material, see the reports listed in 'Key Sections and Material'.

Table 3. Registered specimens of Ballagan Formation ostracods in the British Geological Survey.

long. The specimens of G. lirata in the Ballagan Formation typically bear four costae on the lateral surface of each valve. Their size range $(0.8-1.07 \mathrm{~mm}$ long), suggests they may be juveniles. Despite this, they clearly bear a smaller number of costae than G. costata Hoare, 1991, by which they are readily distinguished. Two small valves from the Glenrothes Borehole (MPA50227, MPK13077; one complete specimen being $0.73 \mathrm{~mm}$ long) possess the typical looped costate ridge of Beyrichiopsis plicata. However, these specimens are small compared to those figured by Robinson (1978, p. 136), which are up to $1.62 \mathrm{~mm}$ long, and it is possible that they are juveniles of G. lirata.
Specimens of Sansabella amplectans (P1. 3, figs 1, 4, 7) from the Ballagan Formation are somewhat older than Roundy's (1926) material from Late Carboniferous (Pennsylvanian) shale in the Marble Falls Limestone of Texas (see Sohn, 1975, p. G7). Robinson (1978, pl. 5) records this species from Holkerian to Upper Asbian horizons of the Viséan. The record from the Ballagan Formation indicates that this species extends down into the Late Tournaisian of Britain. Robinson (1978, pl. 5, figs 3a-d) suggested domiciliar and extra-domiciliar dimorphic features in specimens he referred to $S$. amplectans. All of the Ballagan Formation specimens resemble his heteromorphs.

\section{Explanation of Plate 3.}

Scanning electron micrographs of palaeocopid, podocopid and paraparchitacean ostracods from the Ballagan Formation. figs 1, 4, 7. Sansabella amplectans Roundy, 1926: 1, juvenile carapace, dorsal view, MPK13086, $\times 62 ; 4$, carapace, right lateral view, MPK12474, $\times 54 ; 7$, carapace, left lateral view, MPK12475, $\times 56$. figs 2, 5, 6. 'Bythocypris' aequalis (Jones \& Kirkby, 1886a): 2, carapace, left lateral view, MPK12466, $\times 52$; 5, carapace, left lateral view, MPK12468, $\times 53$; 6, carapace, right lateral view, MPK12465, $\times 54$. figs 3, 12, 14. Paraparchites discus sp. nov.: 3, carapace, dorsal view, MPK12461, $\times 52 ; \mathbf{1 2}$, juvenile carapace, right lateral view, MPK12450, $\times 53 ; \mathbf{1 4}$, carapace, left lateral view, MPK12449, $\times 52$. fig. 8. Shemonaella scotoburdigalensis (Hibbert, 1836) sensu Latham, 1932, carapace, left lateral view, MPK13082, × 46. fig. 9. Glyptopleura lirata Robinson, 1978, holotype, left lateral view, specimen NHM OS7370, from Wath Quarry, Lunedale, Westmorland (fig'd Robinson, 1978), $\times 32$. figs 10, 11, 13. Shemonaella sp. A: 10, juvenile carapace, left lateral view, MPK12463, $\times 52 ; 11$, carapace, left lateral view, MPK12471, $\times 52$; 13, right valve, lateral view, MPK12473, $\times 52$. 


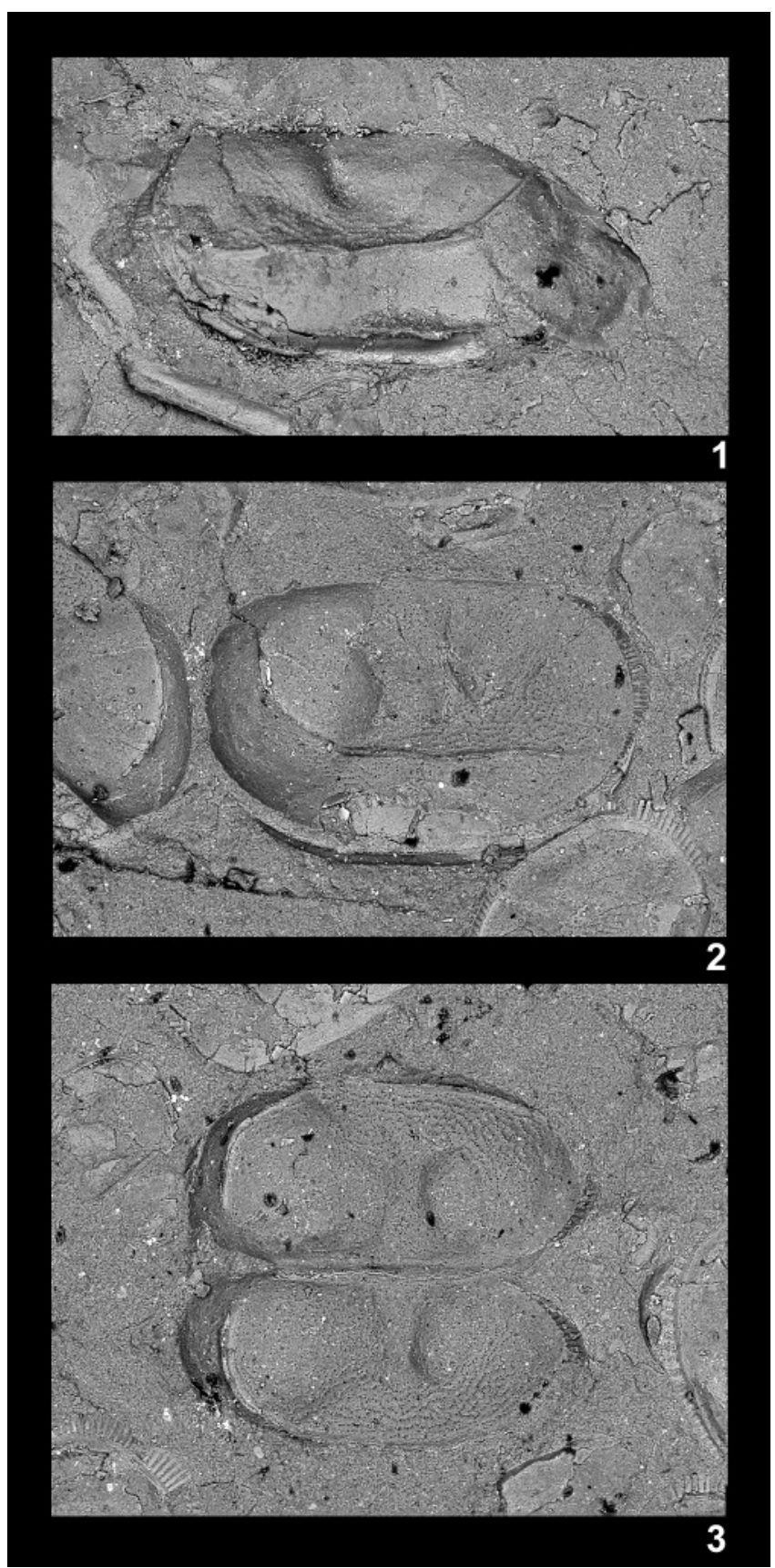

Fig. 7. Scanning electron micrographs of Beyrichiospsis cf. fimbriata (Jones \& Kirkby, 1886b) on rock slab GSE15227 from the Blairmulloch Farm Borehole (depth about $188.7 \mathrm{~m}$ below OD). 1, Flattened tecnomorph(?) left valve, partially obscured dorsally by sediment, and posteroventrally by a juvenile carapace. 2, Heteromorph right valve; velum and valve margin obscured by sediment. 3, Small heteromorph carapace preserved in 'butterfly' (valves open) orientation (right valve bottom). Magnification $\times 49$.

\section{Paraparchitacea Scott}

Three paraparchitacean species are present in the Ballagan Formation, Shemonaella scotoburdigalensis (Hibbert, 1836) sensu Latham (1932), Shemonaella sp. A and Paraparchites discus sp. nov. The latter is described in the Systematic Palaeontology section.
Shemonaella scotoburdigalensis (Hibbert) sensu Latham (1932) (Pl. 3, fig. 8) is recorded widely in the British Lower Carboniferous (e.g. see Jones, 1885; Jones \& Kirkby, 1886a; Latham, 1932; Pollard, 1985), though the original material of Hibbert (1836), that was poorly figured (see Jones \& Kirkby, $1886 a$, p. 255), has not been restudied. Specimens from the Glenrothes Borehole are identical to those in Mary Latham's (1932) collection (palaeontological collections of BGS Edinburgh) referred to $S$. scotoburdigalensis. They have carapaces that are subovate in lateral shape and subamplete to weakly postplete, show weak dorsal overreach of the left valve over the right valve and have evenly convex smooth valves. Some specimens referred to this species have a more ovate amplete lateral shape, for example, that figured by Robinson (1978, pl. 10, fig. 4a) or that from Atlantic Canada figured by Dewey \& Fåhraeus (1987, pl. 7, fig. 5), suggesting a range of variation that might encompass dimorphism and/or more than one species. Jones \& Kirkby (1886a, p. 255) certainly considered S. scotoburdigalensis to be dimorphic, referring to 'thin and fat' specimens, though there are too few specimens to confirm this in the authors' collection.

Shemonaella sp. A (Pl. 3, figs 10, 11, 13) is the most common ostracod in the Ballagan Formation. In its size and shape, and by possessing valves that show marginal flattening particularly anterodorsally and posterodorsally, it resembles the midTournaisian Shemonaella? sp. 66 of Becker \& Bless (1974) and may be conspecific. Small specimens of Shemonaella sp. A resemble $S$. scotoburdigalensis sensu Latham, 1932 (cf. Pl. 3, figs $8,10,11)$, but adults of Shemonaella sp. A are much larger than those $S$. scotoburdigalensis reported by Jones \& Kirkby (1886a, p. 255; 1896, pl. 11, fig. 12) or Latham (1932).

\section{Podocopida G. W. Müller}

Two species of podocopids are present in the Ballagan Formation, Silenites sp. A and 'Bythocypris' aequalis (Jones \& Kirkby, 1886a). The small (less than $1 \mathrm{~mm}$ long) Silenites sp. A (Pl. 2, figs $4,5)$ is rare. The younger (Asbian) species Silenites circumcisa (Jones \& Kirkby, 1879) is much larger: the specimen figured by Robinson (1978, pl. 13, fig. 6a, b) is $1.18 \mathrm{~mm}$ long. Compared with the North American Tournaisian Silenites margaretensis Crasquin, 1985, which is up to $2 \mathrm{~mm}$ long, the Ballagan Formation species is also small. It is also smaller than the type species S. lenticularis (Knight; the senior synonym of Silenites silenus Coryell \& Booth [see Moore, 1961, p. Q387; also see Sohn, 1960, pl. 4, fig. 2]), suggesting that the specimens from the Ballagan Formation are juveniles, or that this is a diminutive new species.

For 'Bythocypris' aequalis (Pl. 3, figs 2, 5, 6) generic identification is made purely on external features - muscle scars and hinge structure are unknown. There are a number of species of Bythocypris that bear some similarity, though Bythocypris Brady is a 'bag-genus' to which numerous species have been referred (for example, see Moore, 1961, p. Q205). 'B.' aequalis also resembles early Darwinula from the Permian and Triassic, although without information on the internal morphology of the carapace, the similarity might be superficial. Jones \& Kirkby (1886a) assigned the species to the Mesozoic and younger Argilloecia. This bears a characteristically broad inner lamella and wide vestibules, whereas in 'B.' aequalis the inner lamella (seen through translucent carapaces) is moderately broad in the 
anterior and posterior (about $0.07-0.1 \mathrm{~mm}$ wide), but narrows along the ventral margin and disappears mid-dorsally. Robinson (1978) assigned Jones \& Kirkby's species to Acutiangulata Buschmina, a Russian bairdiacian genus. Carbonita acutiangulata Posner (in Tschigova, 1960) was later chosen by Buschmina (1968) as the type species of Acutiangulata. Carbonita is a variable genus in terms of shape, but the right valve overlaps the left valve along the free margin (although the left valve may overlap the right valve dorsally) and its characteristic circular adductor muscle pit often has an external representation. The muscle pit is not seen on the Ballagan Formation ' $B$.' aequalis.

\section{SYSTEMATIC PALAEONTOLOGY \\ Class Ostracoda Latreille Subclass Podocopa G. W. Müller Order Palaeocopida Henningsmoen \\ Family Knoxitidae Egorov, 1950 nom. correct Zanina, 1971 (=Geisinidae Sohn in Moore, 1961)}

Genus Knoxiella Egorov, 1950

Type species. Knoxiella semilukiana Egorov, 1950.

Remarks. Knoxiella is characterized by its sub-rectangular lateral shape, sub-circular preadductorial node (when welldeveloped), adductorial sulcus, reticulate ornament in the majority of species, right over left valve overlap, straight ventral overlap contact and domiciliar dimorphism in which the heteromorph carapace is inflated posteriorly. The right valve possesses a straguloid process that overlaps the left valve towards the anterior end of the hinge.

Knoxiella is widespread in the Carboniferous of Europe (e.g. Becker et al., 1974; Robinson, 1978; Coen et al., 1988; Turner et al., 1997) and is also recorded from China (Olempska, 1999).

\section{Knoxiella monarchella sp. nov.}

(Pl. 2, figs 8, 11, 14)

2003 Knoxiella sp. A Stephenson et al.: fig. 9f.

Derivation of name. From the first letters of the surnames of Alison Monaghan and Sarah Arkley of the British Geological Survey, who first collected this species in the rock succession at the Heads of Ayr, Ayrshire, Scotland. Gender feminine.

Diagnosis. Knoxiella with the lateral valve margin flattened anteriorly and posterodorsally, an obsolete preadductorial node which is continuous with the gently convex anterior lobe, ventral outline gently concave in lateral view, and fine reticulate ornament in which the reticulae have diameters of between $20 \mu \mathrm{m}$ and $30 \mu \mathrm{m}$.

Holotype. Heteromorph right valve (MPK12455) mistakenly referred to as a 'carapace' by Stephenson et al. (2003, fig. 9f). From the Ballagan Formation, just to the north of Heads of Ayr, Ayrshire coast.

Material. See Table 3.
Description. Adult valves longer than $1 \mathrm{~mm}$, elongate and subrectangular: valve length about twice the valve height. In lateral view the dorsal outline is essentially straight, the ventral outline weakly concave. Anterior and posterodorsal margin of valves flattened, particularly obvious from a dorsal aspect (Pl. 2, fig. 14). Anterior and posterior lobes gently convex, the latter more inflated in heteromorphs. Adductorial sulcus straight, about one half the valve height and situated about one-third of the valve length from the anterior margin. Posterior part of dorsum weakly epicline in heteromorphs, where the posterior lobe weakly overreaches the dorsum. Straguloid process of larger right valve overreaches the left valve at the anterior end of the hinge (Pl. 2, fig. 14). Right valve overlaps the left valve ventrally; overlap contact straight. Ornament comprises reticulae of diameter between $20 \mu \mathrm{m}$ and $30 \mu \mathrm{m}$, distributed evenly across the valve surface, though often poorly developed in the area of the posterior lobe.

Dimensions. Specimens are $0.83-1.07 \mathrm{~mm}$ long and $0.42-$ $0.58 \mathrm{~mm}$ high (18 measurements).

Remarks. Knoxiella monarchella is characterized by its fine reticulate ornament, in which each reticulum has a diameter of between $20 \mu \mathrm{m}$ and $30 \mu \mathrm{m}$. Of the other described British Knoxiella taxa, K. robusta Robinson, 1978 is much larger, typically reaching lengths of $1.3 \mathrm{~mm}, K$. archdensis (Tschigova) sensu Robinson, 1978 appears to be less elongate and has a more arched lateral outline dorsally, and $K$. cf. rugulosa (Kummerow) sensu Robinson, 1978 has large reticulae. Knoxiella sp. cf. K. clathrata (Kummerow) sensu Turner et al., 1997 from the Viséan Fell Sandstone of northern England has similar overall shape, but is smaller (adult length $0.79 \mathrm{~mm}$ ) than $K$. monarchella and also appears to lack ornament. Of the comparably aged continental European taxa referred to Knoxiella, $K$. clathrata, $K$. rugulosa and $K$. complanata (all Kummerow, 1939) are small (less than $0.9 \mathrm{~mm}$ long). K. subquadrata (Kummerow, 1939) is over $1 \mathrm{~mm}$ long, but its valves are almost smooth. The small (sub-millimetre length) Knoxiella taxa figured by Becker \& Bless (1974) have a more well-developed preadductorial node than $K$. monarchella and more evenly distributed reticulo-punctate ornament (Becker \& Bless, 1974, pl. 22, figs 4-6; pl. 27, figs 6-8; see also Becker et al., 1974, pl. 7, fig. 2a, b), or a gently convex ventral outline in lateral view and reticulo-striate ornament (Becker \& Bless, 1974, pl. 27, figs 1-5; also Becker et al., 1974, pl. 14, figs 7-9), or have smooth valves (Becker \& Bless, 1974, pl. 22, fig. $7 \mathrm{a}-\mathrm{c})$. In lateral shape and possession of a weakly developed preadductorial node, $K$. monarchella is similar to $K$. cf. subquadrata (Kummerow, 1939) and $K$. cf. complanata (Kummerow, 1939) figured by Becker et al. (1974, pl. 14, figs 11, $13,14)$, though in both of these taxa the margin of the valves is not flattened in the manner of $K$. monarchella, and their figured specimens are also smaller than the adults of the Ballagan Formation species. Knoxiella cratigera? (cf. subquadrata) of Coen et al. (1988, pl. 9, figs 7, 8) and their Knoxiella sp. (Coen et al., 1988, pl. 1, fig. 11a, b) are also smaller and show marked carapace flattening near the anterodorsal margin.

Order Leiocopa Schallreuter Superfamily Paraparchitacea Scott, 1959 Family Paraparchitidae Scott, 1959 
Genus Paraparchites Ulrich \& Bassler, 1906

Type species. Paraparchites humerosus Ulrich \& Bassler, 1906.

Remarks. In lateral view the carapace of Paraparchites is characterized by its ovate or elongate-ovate shape, rounded anterior and posterior outlines and straight or weakly convex dorsal margin. It has an incised dorsum, but with limited valve overreach over the hinge-line, an absence of spines on the dorsal lateral surface, insignificant free margin valve overlap and non-sulcate valves (see Sohn, 1971, p. A6). Many species of Paraparchites are differentiated by means of carapace shape and dimensions (Sohn, 1971, 1972). Some Paraparchites, including the type species, show dimorphism, heteromorphs having wider carapaces (see Sohn, 1971; Dewey, 1987).

Paraparchites discus sp. nov.

(P1. 3, figs 3, 12, 14)

2003 Paraparchites sp. 1 Stephenson et al.: fig. 9i.

Derivation of name. Resembling a 'discus' in lateral view (see P1. 3, fig. 14).

Diagnosis. Paraparchites with incised dorsum, demarcated by the overreaching margins of the left and right valves, both of which are drawn out to form narrow ridges at the dorsum in larger valves.

Holotype. A carapace, MPK12449 (Pl. 3, fig. 14), from the Ballagan Formation, just to the north of Heads of Ayr, Ayrshire coast [NGR NS 2977 1871].

Material. See Table 3.

Description. Sub-ovate lateral shape: anterior and posterior lateral outlines evenly convex and rounded, anterior outline slightly more tapering, ventral outline evenly convex. Dorsum umbonate: both valves overreach the dorsal margin and meet at about the same height dorsally. Dorsal margin incised, demarcated by the overreaching margins of the left and right valves, both of which are drawn out to form a narrow ridge at the dorsum in larger valves (Pl. 3, fig. 3). Larger valves have well-developed fine punctation and a smooth central muscle spot, which has a diameter about $20 \%$ of that of the carapace length. Carapaces show right over left valve overlap. Lateral margins of the valves are flattened both anteriorly and posteriorly.

Dimensions. Valves are $0.5 \mathrm{~mm}$ to $1.1 \mathrm{~mm}$ long, representing several moult stages (material from Ayrshire).

Remarks. Valves lack spines, indicating that this is not a species of Shivaella or Shishaella (see Sohn, 1972). Both valves meet at the same height dorsally, their overreach resulting in an epicline dorsum. The latter indicates that this is not a Shemonaella or Chamishaella species either (Dewey \& Fåhraeus, 1987) and serves to distinguish this species from the similarly-sized Shemonaella scotoburdigalensis (Hibbert, 1836).
Paraparchites discus has a more strongly incised dorsum than is typical for the type species P. humerosus (see Sohn, 1971, pl. 1) but, in this respect, is similar to taxa such as Paraparchites sp. of Sohn, 1971 (pl. 2, fig. 16), P. gelasinos Sohn, 1972 and P.? cyclopeus Girty, 1910 (for which, see Sohn, 1969, pl. 8), though the latter possesses a spine on the right valve and is probably not Paraparchites (see Sohn 1971, p. A6). The lateral flattening of the valves anteriorly and posteriorly in $P$. discus is similar to species such as $P$. miseri Sohn, 1972, but $P$. discus differs from that species by lacking indentation along the ventral margin, by which the new species also differs from other Paraparchites such as $P$. gibbosus Upson (see Sohn, 1972). The amplete shape of $P$. discus serves to distinguish it from postplete forms such as P. texanus Delo, 1930 (see Sohn, 1971, pl. 2).

\section{CONCLUSIONS}

The Early Carboniferous Ballagan Formation of the Midland Valley, Scotland, contains an ostracod fauna of 14 species in ten genera, including platycopid (Cavellina, Glyptolichvinella, Sulcella), palaeocopid (Beyrichiopsis, Glyptopleura, Knoxiella, Sansabella), paraparchitacean (Paraparchites, Shemonaella) and podocopid taxa (Silenites, 'Bythocypris'). Two new species are Knoxiella monarchella and Paraparchites discus.

The Ballagan Formation is dominated by ostracod-bearing horizons of low-diversity (one to two species), interpreted as occupying ephemeral aquatic ecologies, with fluctuating salinity (brackish to hypersaline), on a coastal floodplain. Paraparchitacean-dominated assemblages may represent hypersaline conditions. Podocopid-dominated assemblages of 'Bythocypris' aequalis may represent brackish-water conditions, which later in the Ballagan Formation were colonized by the cavellinid Sulcella affiliata. In Ayrshire, higher diversity assemblages of up to five species (cavellinids, palaeocopids and paraparchitaceans) are associated with lithofacies that are interpreted to be tidal flat environments.

The ostracods are useful biostratigraphical markers. Knoxiella monarchella and Cavellina coela have stratigraphical ranges that are coincident with the CM palynomorph Biozone. Sulcella affiliata has a consistent Late CM Biozone occurrence and, thus, affords a local subdivision of that interval in the Midland Valley, which is important for regional correlation.

\section{ACKNOWLEDGEMENTS}

Maxine Akhurst supported this study through the BGS Midland Valley Mapping Project, Mike Browne selected key sections, and Mark Dean provided information about macrofaunas. Chris Dewey (Mississippi), David Siveter (Leicester), an anonymous reviewer and John Gregory (NHM) made reviews and editorial comments that improved this manuscript greatly. The authors also thank David J. Horne (London and NHM) for comments about the higher taxonomy of ostracods, Joanne Green (NIGL) for the isotope analysis, and Paul Shepherd, Grenville Turner and Jim Rayner for help with the SEM and photography. MS, IPW \& ML publish with the Permission of the Executive Director, British Geological Survey (NERC).

\section{Manuscript received 25 February 2004 Manuscript accepted 24 December 2004}




\section{REFERENCES}

Andrews, J.E. \& Nabi, G. 1998. Palaeoclimatic significance of calcretes in the Dinantian of the Cocksburnspath Outlier (East Lothian-North Berwickshire). Scottish Journal of Geology, 34: 153-164.

Andrews, J.E., Turner, M.S., Nabi, G. \& Spiro, B. 1991. The anatomy of an early Dinantian terraced floodplain: palaeoenvironment and early diagenesis. Sedimentology, 38: 271-287.

Andrews, J.E., Riding, R. \& Dennis, P.F. 1997. The stable isotope record of environmental and climatic signals in modern terrestria microbial carbonates from Europe. Palaeogeography, Palaeoclimatology, Palaeoecology, 129: 171-189.

Becker, G. \& Bless, M.J.M. 1974. Ostracode stratigraphy of the ArdennoRhenish Devonian and Dinantian. International Symposium on Belgian Micropalaeontological Limits Publication, 1: 52pp.

Becker, G. \& Bless, M.J.M. 1990. Biotope indicative features in Palaeozoic ostracods: a global phenomenon. In: Whatley, R. \& Maybury, C. (Eds), Ostracoda and Global Events. British Micropalaeontological Society Publication Series. Chapman \& Hall, London, 421-436.

Becker, G., Bless, M.J.M., Streel, M. \& Thorez, J. 1974. Palynology and ostracode distribution in the Upper Devonian and basal Dinantian of Belgium and their dependence on sedimentary facies. Mededelingen Rijks Geologische Dienst, Nieuwe Serie, 25: 9-99.

Brand, U. 1989. Global climatic changes during DevonianMississippian: stable isotope biogeochemistry of brachiopods. Palaeogeography, Palaeoclimatology, Palaeoecology, 75: 311-329.

Browne, M.A.E., Dean, M.T., Hall, I.H.S., McAdam, A.M., Monro, S.K. \& Chisholm, J.I. 1999. A lithostratigraphical framework for the Carboniferous rocks of the Midland Valley of Scotland. British Geological Survey Research Report: RR/99/07.

Bruckschen, P., Oesmann, S. \& Veizer, J. 1999. Isotope stratigraphy of the European Carboniferous: proxy signals for ocean chemistry, climate and tectonics. Chemical Geology, 161: 127-163.

Buschmina, L.S. (Bušmina, L.S.) 1968. Early Carboniferous Ostracoda of the Kuznetsk Basin. Nauka, Moskva, [in Russian].

Coen, M., Michiels, D. \& Parisse, E. 1988. Ostracodes dinantiens de l'Ardenne. Memoires de l'Institut Géologique de l'Université de Louvain, 34: 1-42.

Crasquin, S. 1985. Zonation par les ostracodes dans le Mississippien de l'ouest Canadien. Revue de Paléobiologie, 4: 43-52.

Dean, M. 1998. Faunas from and biostratigraphy of the Blairmulloch Farm, BGS Bore. British Geological Survey Technical Report, WH/98/139R.

Delo, D.M. 1930. Some upper Carboniferous Ostracoda from the shale basin of western Texas. Journal of Paleontology, 4: 152-178.

Dewey, C.P. 1983. Ostracode palaeoecology of the Lower Carboniferous of western Newfoundland. In: Maddocks, R.F. (Ed.), Application of Ostracoda. Eighth International Symposium on Ostracoda, Symposium Volume. University of Houston, 1104-1115.

Dewey, C.P. 1987. Palaeoecology of a hypersaline Carboniferous ostracod fauna. Journal of Micropalaeontology, 6: 29-33.

Dewey, C.P. 2001. Ostracodes as a tool for understanding environmental distribution in the Carboniferous strata of the Eastern United States. Available at: http://www.uky.edu/KGS/coal/webcoal/pages/ ostracodesdewey.html.

Dewey, C.P. \& Fåhræus, L.E. 1987. Taxonomy of Ostracoda (Crustacea) from Mississippian strata of Maritime Canada. Geologica et Palaeontologica, 21: 93-135.

Dewey, C.P. \& Puckett, T.M. 1993. Ostracodes as a tool for understanding the distribution of shelf-related environments in the Chesterian strata of the Black Warrior Basin in Alabama. In: Pashin, J.C. (Ed.), New perspectives on the Mississippian System of Alabama. A Guidebook for the 30th Annual Field Trip of the Alabama Geological Society. Alabama Geological Society, 61-68.

Dewey, C.P., Puckett, T.M. \& Devery, H.B. 1990. Palaeogeographical significance of ostracod biofacies from Mississippian strata of the Black Warrior Basin, northwestern Alabama: a preliminary report. In: Whatley, R. \& Maybury, C. (Eds), Ostracoda and Global Events British Micropalaeontological Society Publication Series. Chapman \& Hall, London, 527-544.

Egorov, V.G. 1950. Ostracoda of the Frasnian Stage of the Russian Platform. 1, Kloedenellidae. Trudy, VNIGRI, Moscow, 1-40 [in Russian]
Girty, G.H. 1910. New genera and species of Carboniferous fossils from the Fayetteville shale of Arkansas. New York Academy of Science Annals, 20: 189-238.

Hantzschel, W. 1975. Trace fossils and problematica. In: Teichert, C. (Ed.), Treatise on Invertebrate Paleontology, Part W, Miscellanea Supplement 1, 1. Geological Society of America and University of Kansas Press, Boulder, Colorado and Lawrence, Kansas.

Hibbert, S. 1836. On the Freshwater Limestone of Burdiehouse in the Neighbourhood of Edinburgh, belonging to the Carboniferous Group of rocks: Section IV. The microscopic Animals contained in the Limestone of Burdiehouse. Transactions of the Royal Society of Edinburgh, 13: 178-180.

Hoare, R.D. 1991. Ontogeny and variation in Glyptopleura costata (MCCoy) (Ostracoda: Mississippian, Chesterian) from Ohio. Journal of Paleontology, 65: 760-766.

Horne, D.J., Cohen, A. \& Martens, K. 2002. Taxonomy, morphology and biology of Quaternary and living Ostracoda. The Ostracoda: Applications in Quaternary Research. Geophysical Monograph, 131: 5-36.

Jones, T.R. 1885. Notes on the late Mr George Tate's specimens of Lower Carboniferous Entomostraca from Berwickshire and Northumberland. Proceedings of the Berwickshire Naturalists' Club, 10 (2): 313-325.

Jones, T.R. \& Kirkby, J.W. 1879. Descriptions of the species of the ostracodous genus Bairdia $\mathrm{M}^{\circ} \mathrm{Coy}$ from the Carboniferous strata of Great Britain. Quarterly Journal of the Geological Society, London, 35: $565-581$.

Jones, T.R. \& Kirkby, J.W. 1886a. Notes on the Palaeozoic bivalved Entomostraca-No. XXII. On some undescribed species of British Carboniferous Ostracoda. Annals and Magazine of Natural History, Series 5, 18: 249-269.

Jones, T.R. \& Kirkby, J.W. 1886b. On some fringed and other Ostracoda from the Carboniferous Series. Geological Magazine, Decade 3, 3: 433-439.

Jones, T.R. \& Kirkby, J.W. 1896. On Carboniferous Ostracoda from Ireland. Scientific Transactions of the Royal Dublin Society, Series 2, 6: $173-200$.

Kummerow, E. 1939. Die Ostrakoden und Phyllopoden des deutschen Unterkarbons. In: Die Fauna des deutschen Unterkarbons, Teil 4. Abhandlungen der Preussischen Geologischen Landesanstalt, Berlin, 194: 6-107.

Latham, M.H. 1932. Scottish Carboniferous Ostracoda. Transactions of the Royal Society of Edinburgh, 57: 351-395.

Leng, M.J. \& Marshall, J.D. 2004. Palaeoclimate interpretation of stable isotope data from lake sediments. Quaternary Science Reviews, 23: 811-831.

Lumsden, G.I., Tulloch, W., Howells, M.F. \& Davies, A. 1967. The geology of the neighbourhood of Langholm. Memoirs of the Geological Survey, Scotland.

Lundin, R.O. 1987. On Glyptolichvinella spiralis (Jones \& Kirkby). Stereo-Atlas of Ostracod Shells, 14: 139-142.

Lundin, R.O. \& Visintainer, L.M. 1987. On Glyptolichvinella ovicella sp. nov. Stereo-Atlas of Ostracod Shells, 14: 143-148.

Mitchell, G.H. \& Mykura, W. 1962. The geology of the neighbourhood of Edinburgh 3rd Edition. Memoir of the Geological Survey, Scotland, Sheet 32 .

Moore, R.C. 1961. Treatise on Invertebrate Paleontology Part Q, Arthropoda 3, Crustacea, Ostracoda. Geological Society of America and University of Kansas Press, Boulder, Colorado and Lawrence, Kansas.

Neves, R., Gueinn, K.J., Clayton, G., Ioannides, N. \& Neville, R.S.W. 1972. Scheme of miospore zones for the British Dinantian. 7th Congrès International de Stratigraphie et de Géologie du Carbonifére, Krefeld, 1979, Compte Rendu, 1: 347-353.

Neves, R., Gueinn, K.J., Clayton, G., Ioannides, N.S., Neville, R.S.W. \& Kruszewska, K. 1973. Palynological correlations within the Lower Carboniferous of Scotland and Northern England. Transactions of the Royal Society of Edinburgh, 69: 4-70.

Olempska, E. 1999. Silicified shallow-water ostracodes from the Early Carboniferous of South China. Acta Palaeontologica Polonica, 44: 383-436.

Pollard, J. 1985. Coprolites and ostracods from the Dinantian of Foulden, Berwickshire, Scotland. Transactions of the Royal Society of Edinburgh: Earth Sciences, 76: 49-51. 
Robinson, E. 1978. The Carboniferous. In: Bate, R.H. \& Robinson, E. (Eds), Stratigraphical Index of British Ostracoda. Geological Journal Special Issue, 8: 121-166.

Rome, D.R. 1973. Contribution á l'étude des Ostracodes du Tournaisian inférieur de la Belgique. Bulletin Sociétié Belge Géologie Paléontologie Hydrogéologie, 82: 301-349.

Roundy, P.V. 1926. Mississippian Formations of San Saba County, Texas: Part 2. The Micro-Fauna. United States Geological Survey Professional Paper, 146: 5-8.

Scott, H.W. 1959. Type species of Paraparchites Ulrich \& Bassler. Journal of Paleontology, 33: 670-674.

Sohn, G. 1960. Paleozoic species of Bairdia and related genera. United States Geological Survey Professional Paper, 330A: 1-105.

Sohn, G. 1969. Revision of some of Girty's invertebrate fossils from the Fayetteville Shale (Mississippian) of Arkansas and Oklahoma ostracodes. United States Geological Survey Professional Paper, 606: $41-59$.

Sohn, G. 1971. New Late Mississippian ostracode genera and species from northern Alaska: a revision of the Paraparchitacea. United States Geological Survey Professional Paper, 711A: 1-24.

Sohn, G. 1972. Late Paleozoic osracode species from the conterminous United States. United States Geological Survey Professional Paper, 711: $1-15$.

Sohn, G. 1975. Mississippian Ostracoda of the Amsden Formation (Mississippian and Pennsylvanian) of Wyoming. United States Geological Survey Professional Paper, 848G: 1-22.

Stephenson, M., Williams, M., Monaghan, A., Arkley, S. \& Smith, R. 2003 (for 2002). Biostratigraphy and palaeoenvironments of the Ballagan Formation (lower Carboniferous) in Ayrshire, SW Scotland. Scottish Journal of Geology, 38: 93-111.

Stephenson, M.H., Williams, M., Leng, M. \& Monaghan, A. 2004a. Aquatic plant microfossils of probable non-vascular origin from the Ballagan Formation (Lower Carboniferous), Midland Valley, Scotland. Proceedings of the Yorkshire Geological Society, $\mathbf{5 5}$ $145-158$.

Stephenson, M.H., Williams, M., Monaghan, A. et al. 2004b. Palynomorph and ostracod biostratigraphy of the Ballagan Formation, Midland Valley of Scotland and elucidation of intra Dinantian unconformities. Proceedings of the Yorkshire Geological Society, 55: $131-143$.

Tibert, N.E. \& Scott, D.B. 1999. Ostracodes and agglutinated foraminifera as indicators of paleoenvironmental change in an Early Carbon- iferous brackish bay, Atlantic Canada. Palaois, 14: 246-260.

Tschigova, V.A. 1960. Age and ostracode correlations of the Lower Malinowski deposits of the Kamsko-Kinelskoi Basin based on the study of ostracodes. Trudy, VNII Leningrad, 30: 169-233 [in Russian].

Tucker, M., Gallagher, J., Lemon, K. \& Leng, M. 2003. The Yoredale Cycles of Northumbria: high frequency clastic-carbonate sequences of the mid-Carboniferous icehouse world. Open University Geological Society Journal, 24 (2): 5-10.

Turner, M.S. 1991. Geochemistry and diagenesis of basal Carboniferous dolostones from southern Scotland. PhD thesis. University of East Anglia, 357pp.

Turner, B.R., Dewey, C. \& Fordham, C.E. 1997. Marine ostracods in the lower Carboniferous fluviatile Fell Sandstone Group: evidence for base level change and marine flooding of the central graben, Northumberland Basin. Proceedings of the Yorkshire Geological Society, 51: 292-306.

Ulrich, E.O. \& Bassler, R.S. 1906. New American Paleozoic Ostracoda. Notes and descriptions of Upper Carboniferous genera and species. Proceedings United States National Museum, Washington, 30: 149-164.

Veizer, J., Ala, D., Azmy, K. et al. 1999. 87Sr/86Sr, d13C and d18O evolution of Phanerozoic seawater. Chemical Geology, 161: 59-88.

Williams, M. 2002. Lower Carboniferous ostracods from the Ballagan Formation, Midland Valley, Scotland: analysis of the Spilmersford Borehole; improved analysis of the Glenrothes Borehole; and a review of stratigraphical and palaeoecological ostracod data from key sections. British Geological Survey Technical Report: IR/02/194.

Wilson, R.B. 1989. A study of the Dinantian marine macrofossils of central Scotland. Transactions of the Royal Society of Edinburgh: Earth Sciences, 80: 91-126.

Young, S.W. 1867a. On the Ballagan series of rocks. Transactions of the Geological Society of Glasgow, 2: 209-212.

Young, S.W. 1867b. On the presence of magnesia in rocks. Transactions of the Geological Society of Glasgow, 2: 64-68.

Yurtsever, Y. \& Gat, J.R. 1981. Atmospheric waters. In: Gat, J.R. \& Gonfiantini, R. (Eds), Stable Isotope Hydrology. IAEA Technical report Series, 210: 103-142.

Zanina, I.E. 1971. Ostracoda from the Lower Carboniferous key section at Kizelov. In: Ivanova, V.A. (Ed.), Palaeozoic Ostracoda from key sections in the European part of the USSR, Moscow, 134-183, 242-247 [in Russian]. 